\title{
EXTENDING THE FANTASY IN THE SUPERMARKET: WHERE UNHEALThY FoOd PROMOTIONS MEet ChILDREN AND HOW THE GOVERNMENT CAN INTERVENE
}

\author{
Jennifer L. Pomeranz, JD, MPH*
}

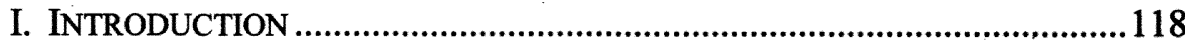

II. THE RETAIL ENVIRONMENT ...........................................................119

A. Background and Definitions ...................................................119

B. Food Promotions Directed at Children ....................................... 121

C. Industry Self Regulatory Pledges and Nutritional Quality

of Food Promoted to Youth ........................................................... 123

III. RESEARCH ON EFFECTIVENESS OF CHILD-TARGETED PROMOTIONS .126

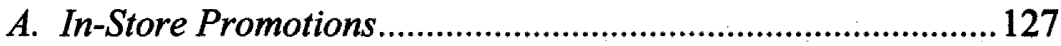

B. Packaging and Packaging Promotions....................................131

1. Licensed Characters and Company Spokescharacters.......132

2. Other Package Promotion Techniques ................................135

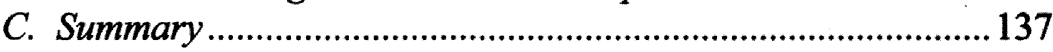

IV. REgUlATING IN-STORE AND PACKAGE PROMOTIONS TO PROTECT

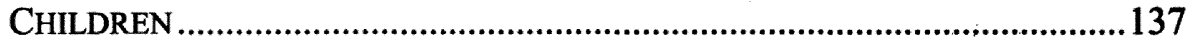

A. Government's Role in the Protection of Children ...................139

B. Regulating the Food Retail Environment................................144

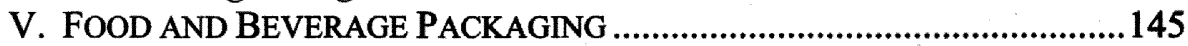

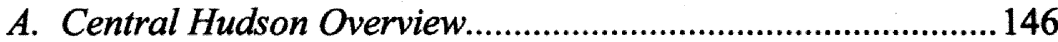

$B$. Government Restrictions on the Use of Characters on

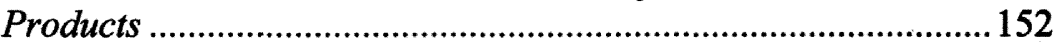

1. Characters are Deceptive and Misleading Under Prong

One of Central Hudson ...............................................................152

2. Refuting Industry Responses................................................157

3. Character Restrictions Should Pass the Central Hudson

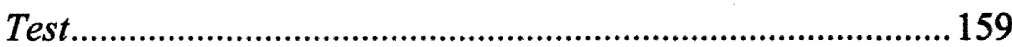

C. Other Package Restrictions .....................................................164

VI. REGULATION OF IN-STORE PROMOTIONS AND PLACEMENT ................166

A. In-Store Advertising Restrictions .............................................166

B. In-Store Regulations of Conduct..............................................168

1. Non-expressive and Expressive Conduct ..............................168

2. Other Standards to Regulate Conduct ...................................173

C. Constitutional Analysis of the In-Store Regulations.................175

1. Regulating Product Location Based on Nutritional

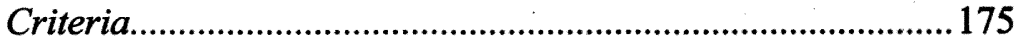

2. Regulating Product Location Based on Nutritional

* Director of Legal Initiatives at Rudd Center for Food Policy \& Obesity, Yale; MPH, 2006, Harvard School of Public Health; J.D., 2000, Cornell Law School. 
Criteria and Character Use 177

a. Analysis under O'Brien.

b. O'Brien inquiry continued.

VII. CONCLUSION 185

\section{INTRODUCTION}

The first exposure to the marketplace for most children comes as soon as they become a passenger in a shopping car at the grocery store. ${ }^{1}$ Although they do not yet know it, they are being marketed to by the food and beverage industry through packages, promotions, and displays surrounding them during this shopping experience. The marketing of unhealthful foods to children is a significant contributor to the epidemic of childhood obesity. ${ }^{2}$ The FTC found that in 2006, food and beverage companies expended $\$ 195$ million, second only to the amount spent on television advertising, on packaging and in-store displays targeted to children and adolescents. Since then marketing within retail establishments has grown rapidly. Almost all of the products marketed to children in retail establishments are for food of low nutritional value and tend to be high in salt, sugar, or fat. ${ }^{3}$ Industry selfregulatory pledges do not apply to this environment, and researchers have recently begun to systematically look at the retail environment and its relationship to children's nutrition-related beliefs and behaviors. ${ }^{4}$

The primary means of in-store marketing are front-of-package design (especially the depiction of characters popular with children) and the strategic placement of the products within the store (e.g., placement in check-out aisles and free standing displays). Packaging and displays are particularly important to capture the interest of young children who have limited ability to read. ${ }^{5}$ In fact, food companies use trained psychologists to create posi-

1. Deborah John, Consumer Socialization of Children: A Retrospective Look at Twenty-Five Years of Research, 26 J. CONSUMER RES. 183, 192 (1999).

2. Cynthia Ogden et al., High Body Mass Index for Age Among U.S. Children and Adolescents, 2003-2006, 299 JAMA 2401 (2008).

3. See, e.g., Jonathan Lynn, WHO Recommends Food Marketing Curbs for Child Obesity, REUTERS, Jan. 21, 2011, available at http://www.reuters.com/article/2011/01/21/usfood-safety-idUSTRE70K4FU20110121; see also Stacy Finz, Front Labels on Food for Children Called Deceptive, S.F. CHRON., Jan. 20, 2011, at A-1, available at http://www.sfgate.com/cgi-bin/article.cgi?f=/c/a/2011/01/20/MNJM1HBICE.DTL.

4. See, e.g., Jennifer L. Harris et al., Marketing Foods to Children and Adolescents: Licensed Characters and Other Promotions on Packaged Foods in the Supermarket, 13 PUB. HEALTH NUTRITION 409 (2009).

5. Billur Ülger, Packages with Cartoon Trade Characters Versus Advertising: An Empirical Examination of Preschoolers' Food Preferences, 15 J. FoOD ProDucts MARKETING 104 (2009). 
tive reactions in children upon seeing their products. ${ }^{6}$ The majority of foods marketed to children in retail stores feature characters on the packaging, which has been shown to manipulate children's food related beliefs and induces them to request these products to their parents. ${ }^{7}$ This promotional method undermines the parents' role as "nutritional gatekeeper" and has been shown to strain parent-child interactions. ${ }^{8}$

From the industry's perspective, "point-of-purchase materials" are "intended to lure young fans" of a popular character, movie or the like to the food product bearing the character, such as for Pokemon cereal. ${ }^{9}$ For example, at the inception of Barbie cereal, when $95 \%$ of girls ages three to ten owned at least one Barbie, industry representatives explained that the product would be part of the "exciting and glamorous world of Barbie" and "extends the fantasy" for "little girls who 'play Barbie.",10

This paper summarizes research concerning the extent of in-store marketing of foods to children and the effects of such marketing. Next it identifies several different ways that the federal and state or local governments might regulate in-store and package-based marketing and industry arguments against such regulations. Finally, it analyzes how courts would likely scrutinize the constitutionality of such regulations to identify which approaches are most likely to make a positive impact on public health and succeed if challenged in court.

\section{THE RETAIL ENVIRONMENT}

\section{A. Background and Definitions}

Marketing within food retail establishment has been increasing and projections state that this is the "fastest-growing area of marketing investment for packaged-goods marketers." ${ }^{11}$ The most recent industry reports indicate that $83 \%$ of food, beverage and consumer product marketers plan to increase investments into what the industry terms, "shopper marketing." 12 Shopper marketing is defined as, "the employment of any marketing

6. BRIAN WilcoX ET AL., REPORT OF THE APA TASK FoRCE ON ADVERTISING AND ChILDREN 20 (2004).

7. See Part III.B., infra.

8. FAQ About the Book, MINDLESSEATING.ORG, http://mindlesseating.org/faq.php (last visited Oct. 30, 2011).

9. Stephanie Thompson, Kellogg's New Cereal Goes Pokemon, AdVERTISING AGE, Mar. 13, 2000, at 6, available at http://adage.com/article/news/kellogg-s-cerealpokemon/59084/.

10. Cyndee Miller, Cereal Maker to Kids: Eat Breakfast with Barbie, MARKETING NEws, Sept. 25, 1989, at 10 (internal quotation marks omitted).

11. Jack Neff, Shopper Marketing Trumps Digital in Spending Plans for CPG Marketers, ADVERTISING AGE, Nov. 9, 2010, available at $\mathrm{http}: / /$ adage.com/article/news/shoppermarketing-trumps-digital-spending-plans-cpg/146959/.

12. Sarah Mahoney, Shopper Marketing Grows Faster than Digital, Social, 
stimuli, developed based on a deep understanding of shopper behavior, designed to build brand equity, engage the shopper (i.e., an individual in "shopping mode"), and lead him/her to make a purchase." Grocery Manufacturers Association ("GMA") and Deloitte explained the premise behind shopper marketing:

[M]anufacturers and retailers can together create a more engaging shopper experience, influencing shoppers at the point of purchase where they make most final buying decisions. Shopper marketing is about using insights, ... to deliver the right environment, right products, right packaging, right prices, and right marketing communication-combined to satisfy the shopper in a way that was not traditionally possible. ${ }^{14}$

Shopper marketing studies typically analyze shoppers in general so promotional techniques intended directly for children are not often reported separately. One exception is the technique termed, the "nag factor," defined as "an indirect path beginning with promotional activities influencing children, who then request that their parent(s) buy the product, followed by the parent(s) making the decision and/or purchase."15 The retail environment is a concern for public health and child advocates because the majority of food targeted to youth in this venue is of poor nutritional value, and promotions encourage children to request (and prefer) these unhealthy products.

The "bread and butter" of shopper marketing is considered to be product packaging and in-store displays, ads, and promotions. ${ }^{16}$ This manuscript will focus on the two main areas of shopper marketing: packaging and in-store promotions and displays, while touching on related tools. The definitions used by the Federal Trade Commission ("FTC") when it ordered forty-four food and beverage companies to disclose information on their marketing expenditures directed at children and adolescents (collectively "youth") are helpful. ${ }^{17}$

MEDIAPost PUB. (Nov. 9, 2010, 5:00 AM), http://www.mediapost.com/publications/article/ $139107 /$.

13. GMA \& Deloitte, Shopper Marketing Study: Delivering the Promise of SHOPPER MARKETING 8 (2008), available at http://www.deloitte.com/assets/DcomUnitedStates/Local\%20Assets/Documents/us_cb_cpg_DeloitteGMA_Shopper_Mkt_Report_ 200810.pdf.

14. Id.

15. Eileen Bridges \& Richard Briesch, The 'Nag Factor' \& Children's Product Categories, 25 INT'L J. ADVER. 157, 157-58 (2006).

16. GMA SAles COMm. \& Booz \& Co., Shopper Marketing 4.0: BuILding Scalable Playbooks that DRIVE Results 5 (2010), available at $\mathrm{http} / / / \mathrm{www}$.gmaonline.org/downloads/research-and-reports/Shopper_Marketing_4.0.pdf.

17. For all FTC definitions, children were categorized as younger than twelve years and adolescents twelve to seventeen years old. See, e.g., FED. TRADE CoMm'N, MARKETING FOOD TO CHILDREN AND ADOLESCENTS: A REVIEW OF INDUSTRY EXPENDITURES, ACTIVITIES, 
Packaging includes all product packaging and labeling (including all words and images) for any of the company's food products designed to appeal to youth. ${ }^{18}$ According to federal law, written, printed, or graphic matter accompanying the product is considered part of the label, such as a shelf tag with a character promoting the product placed on the accompanying shelf. ${ }^{19}$

Influential features on packaging were also independently measured by the FTC including the use of character licensing, toy co-branding, celebrity endorsements, and cross-promotions - the linking of a food or beverage to a licensed character, a new movie, or a popular television program. ${ }^{20}$ In addition, the use of premiums was individually measured, and premiums are defined as non-food specialty items distributed in connection with the product within food packages or by sale or the redemption of coupons, codes, or proofs of purchase. ${ }^{21}$ In-store advertising and promotions include "advertising displays and promotions at a retail site, including the offering of free samples and allowances paid to facilitate shelf placement or merchandise displays" designed to appeal to youth. ${ }^{22}$

\section{B. Food Promotions Directed at Children}

\section{The FTC's Food Marketing Report found that food and beverage}

AND Self-Regulation 1 (2008) [hereinafter MaRKeting Food to CHILDREN AND ADOLESCENTS], available at www.ftc.gov/os/2008/07/P064504foodmktingreport.pdf.

18. This includes: prominently featured youth-oriented licensed characters, celebrity endorsers, models or characters who are or appear to be younger than age eighteen, language, such as "kid," "child," "tween," "adolescent," "teen," "teenager," or similar words, or youth-oriented themes, activities, incentives, products, or media. FEDERAL TRADE COMM'N, MARKETING FoOD TO CHILDREN \& ADOLESCENTS: A REVIEW OF INDUSTRY EXPENDITURES, ACtivities, \& SElF-REgUlation: APPENDICES B-16, B-30 (2008) [hereinafter MARKETING FOOD TO CHILDREN AND ADOLESCENTS: APPENDICES], available at http://www.ftc.gov/ os/2008/07/P064504foodmktingreportappendices.pdf.

19. The Federal Food, Drug and Cosmetic Act defines label to mean "a display of written, printed, or graphic matter upon the immediate container of any article," 21 U.S.C. $\S$ $321(\mathrm{k})$ (2009), and the term "labeling" means "all labels and other written, printed, or graphic matters (1) upon any article or any of its containers or wrappers, or (2) accompanying such article," 21 U.S.C. $\$ 321(\mathrm{~m})(2009)$. The Supreme Court found that the definition of labeling covered a pamphlet with literature about the product that was shipped with the product but also interpreted it to include the pamphlet if it was available separately. Kordel v. United States, 335 U.S. 345, 347-50 (1948). In a case more on point, a district court relied on this precedent to find that in-store statement: "vitamins + water = what's in your hand" that "accompanied the sale" of the beverage vitaminwater constituted labeling. Ackerman v. Coca-Cola Company, 2010 U.S. Dist. LEXIS 73156, at *16, *25-26 (E.D.N.Y. July 21,2010 ) (The court was not explicit but likely the statement was on a shelf-tag.).

20. MARKETING FOOD TO CHILDREN AND ADOLESCENTS: APPENDICES, supra note 14, at B-20, B-23-24, B-34-35, B-37-38.

21. Id. at B-18-19, B-32-33.

22. Such design elements may involve the height of placement or display to reach youth, and the use of licensed characters, images of youth, and language such as "kid," "child," "adolescent" "teen," "teenager," or similar words. MARKETING FOOD TO CHILDREN AND ADOLESCENTS: APPENDICES, supra note 14, at B-18, B-32. 
companies spent $\$ 195$ million on packaging and in-store display materials to reach children and adolescents. ${ }^{23}$ This represents $12 \%$ of all reported youth marketing expenditures and is second only to television advertising. ${ }^{24}$ The products marketed to youth in this manner included in decreasing order of expenditures: snacks, breakfast cereals, carbonated beverages and candy/frozen desserts, and juice and non-carbonated beverages. ${ }^{25}$ Nearly $\$ 90$ million ( $46 \%$ of all youth-directed expenditures for packaging and in-store marketing) was spent on teen-directed marketing of carbonated beverages alone. ${ }^{26}$ Studies show that young children as well as teens are influenced by teen-directed marketing in the retail environment. ${ }^{27}$

The FTC found that integrated advertising campaigns, which combine several marketing techniques and often involve cross-promotions, dominate today's landscape of food marketing to youth. Cross-promotions are used in many media venues (e.g., television, packaging, internet), account for $13 \%$ of all reported youth-directed marketing expenditures, and involve the use of licensed characters spokescharacters, games, contests, sweepstakes, movie and television tie-ins, toys, and entertainment events. ${ }^{28}$

Finally, the companies reported spending $\$ 67$ million to reach youth through premiums, which accounted for $4 \%$ of all marketing expenditures. Child-targeted breakfast cereals accounted for $93 \%$ of all expenditures on premiums (approximately $\$ 40$ million). ${ }^{29}$ It is important to note that this does not represent all premiums directed at youth because the companies reported that cross-promotional partners often covered the cost of premi-

23. Study of Food Industry Marketing to Children and Adolescents; Orders to File Special Report, FTC Matter No.: P094511, FED. TRADE COMM'N, http://www.ftc.gov/ os/6b_orders/foodmktg6b/P094511/index.shtm (last modified Aug. 27, 2010) (In 2010, the FTC subpoenaed forty-eight food and beverage companies gain information advertising expenditures and methods for the year 2009 and to determine whether self-regulation was having the appropriate impact on marketing to children. Some companies of the original forty-four were left off the new list and twelve new companies were subpoenaed); see also Rich Thomaselli, FTC Subpoenas 48 Food Companies Regarding Marketing to Kids, ADVERTISING AGE, Sept. 1, 2010, available at $\mathrm{http}: / /$ adage.com/article?article_id=145675.

24. MARKETING FoOD TO CHILDREN AND ADOLESCENTS, supra note 13, at 8.

25. Id.

26. Id. at 18 (The next largest in store expenditure was $\$ 18.2$ million for snacks).

27. See Phyllis Ellickson et al., Does Alcohol Advertising Promote Adolescent Drinking? Results From a Longitudinal Assessment, 100 ADDICTION 235 (2005), available at http://onlinelibrary.wiley.com/doi/10.1111/j.1360-0443.2005.00974.x/pdf (reporting that, among other findings, for seventh-grade non-drinkers, exposure to in-store beer displays predicted drinking onset by grade nine); Sandy Slater et al., The Impact of Retail Cigarette Marketing Practices on Youth Smoking Uptake, 161 ARCHIVES OF PEDIATRIC \& ADOLESCENT MED. 440 (2007), available at http://archpedi.ama-assn.org/cgi/reprint/161/5/440.pdf (finding that cigarette retail marketing practices increase the likelihood of smoking uptake in youth); cf. Hazelwood Sch. Dist. v. Kuhlmeier, 484 U.S. 260, 274-75 (1988) ("It was not unreasonable for the principal to have concluded that such frank talk was inappropriate in a school-sponsored publication distributed to 14-year-old freshmen and presumably taken home to be read by students' even younger brothers and sisters.").

28. MARKETING FOOD TO CHILDREN AND ADOLESCENTS, supra note 13, at 8.

29. Id. at 19. 
ums. ${ }^{30}$

In 2005, the Institute of Medicine ("IOM") found that child-targeted food products are high in total calories, sugars, salt, fat, and low in nutrients. $^{31}$ The food identified by the FTC study as those most promoted to children in 2006 through packaging, premiums, and in-store marketing are considered non-nutritious by objective nutrition criteria and scientific research: snacks, breakfast cereals, carbonated beverages, candy, frozen desserts, and non-carbonated beverages. ${ }^{32}$ More recent studies have confirmed that this environment has not improved despite the fact that in 2006 the Council of Better Business Bureaus and leading food and beverage companies launched the Children's Food and Beverage Advertising Initiative ("CFBAI") "to shift the mix of advertising primarily directed to children ('child-directed advertising') to encourage healthier dietary choices and healthy lifestyles."33

\section{Industry Self Regulatory Pledges and Nutritional Quality of Food Pro- moted to Youth}

Fifteen packaged food and beverage manufacturers are members of the CFBAI. ${ }^{34}$ Through their pledges, these companies vowed to restrict their

30. Id. Partners, such as a toy or media company, often covered the premium costs, such as sweepstakes prizes or DVD rebates. $I d$.

31. COMM. ON FoOd MKTG. AND THE DiETS OF CHILDREN AND Youth, INST. OF MED., FOOD MARKETING TO CHILDREN AND YOUTH: THREAT OR OPPORTUNITY? 163 (2005).

32. JenNifer L. Harris et al., YAle RUdd Center For FoOd POlicy \& OBesity, CEREAL F.A.C.T.S.: EVALUATING THE NUTRITION QUALITY AND MARKETING OF CHILDREN'S

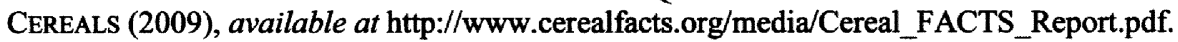
For example, carbonated beverages and other sugar-sweetened drinks have been determined to be the largest single contributor to obesity and an independent risk factor for diabetes and heart disease. Vasanti Malik et al., Sugar-Sweetened Beverages, Obesity, Type 2 Diabetes Mellitus, and Cardiovascular Disease Risk, 121 CiRCulATION 1356 (2010); Vasanti Malik et al., Intake of Sugar-Sweetened Beverages and Weight Gain: A Systematic Review, 84 AM. J. CliniCAL Nutrition 274 (2006); Samara Nielsen \& Barry Popkin, Changes in Beverage Intake Between 1977 and 2001, 27 AM. J. PREVENTIVE MED. 205 (2004); David Ludwig et al., Relation Between Consumption Of Sugar-Sweetened Drinks and Childhood Obesity; A Prospective, Observational Analysis, 357 THE LANCET 505 (2001) (finding that a child's risk of becoming obese increases by $60 \%$ for each serving of sugar sweetened beverage the child drinks each day).

33. About Children's Food and Beverage Advertising Initiative, BETTER BUSINESS BUREAU, http://www.bbb.org/us/about-children-food-beverage-advertising-initiative/ (last visited Feb. 26, 2012).

34. The food companies are: Cadbury Adams, USA, LLC, Campbell Soup Company, The Coca-Cola Company, ConAgra Foods, Inc., The Dannon Company, General Mills, Inc., The Hershey Company, Kellogg Company, Kraft Foods Global, Inc., Mars, Inc., Nestlé USA, PepsiCo, Inc., Post Foods, LLC, Sara Lee Corp., Unilever United States. Two restaurants are also members but are not included in this analysis: Burger King Corp., McDonald's USA. See Karlene Lukovitz, Industry Unveils New Marketing-to-Kids Standards, MEDIAPOST PUB. (July 15, 2011, 9:29 AM), http://www.mediapost.com/publications/article/ 154139/industry-unveils-new-marketing-to-kids-standards.html. 
use of certain marketing practices via specific media to food that meets their own internal nutritional criteria. ${ }^{35}$ Although each company's pledge is unique, the CFBAI announced that uniform nutrition standards would be launched on December 31, 2013. ${ }^{36}$

The stated goal of CFBAI is to promote and support healthier dietary choices and healthy lifestyle to children under twelve years of age. ${ }^{37} \mathrm{How}-$ ever, the CFBAI Core Principles Statement explains that participants' commitments explicitly exclude point of sale materials, packaging, and the use of company-owned characters. ${ }^{38}$ No pledge covers in-store marketing and only two companies have a minimal exception for their products' packaging; Kellogg's and General Mills restricts their use of third-party childdirected licensed characters on packaging according to internal nutrition standards. ${ }^{39}$ However, both of these companies have a wide variety of wellestablished company spokescharacters for their products intended for children (e.g., the Lucky Charms Leprechaun, the Trix Rabbit, Tony the Tiger, and Snap, Crackle and Pop) that they use on their packaging.

There are no pledges addressing the use of company spokescharacters on packaging or in-store promotions. Child-targeted food product packaging also bears other promotions including the use of premiums, crosspromotions, tie-ins for movies and television shows, games, puzzles, contests, sweepstakes, special colors, shapes or flavors, and claims or allusions to fun. ${ }^{40}$

35. Core Principles Statement states that the pledges cover some or all of the following media: television, print, radio, internet, video/computer games, DVDs, cell phones, PDAs, and word of mouth advertising. See BETTER BUSINESS BUREAU, CHILDREN's FOOD \& Beverage AdVertising Initiative Program \& Core Principles Statement (2010), available at http://www.bbb.org/us/storage/0/Shared\%20Documents/Enhanced\%20Core\% 20Principles\%20Third\%20Edition\%20-\%20Letterhead.pdf.

36. About Children's Food and Beverage Advertising Initiative, BETTER BUSINESS BUREAU, http://www.bbb.org/us/about-children-food-beverage-advertising-initiative/ (last visited Feb. 26, 2012).

37. The pledges state that the companies will limit the use of one or all of the following: licensed characters, celebrities, athletes and movie-tie-ins, to covered media according to their own internal nutrition criteria. Eight of the pledges say they do not advertise to children under six years old. See id; see also Pre-2010 Company Pledges, BETTER BUSINESS BUREAU, http://www.bbb.org/us/children-food-beverage-advertising-initiative/pledges/ (last visited Oct. 1, 2011).

38. BETTER BUSINESS BUREAU, supra note 33 (Unilever and Campbell's Soup also explicitly exclude packaging and in-store promotions from their pledges).

39. Id. General Mills limits its use of third-party child-directed licensed characters to packaging for products that meet its Healthy Dietary Choice criteria and sugar guideline. BETTER BUSINESS BUREAU, THE CHILDREN's FOOD \& BEVERAGE ADVERTISING INITIATIVE IN ACTION: A REPORT ON COMPLIANCE AND IMPLEMENTATION DURING 200834 (2009), available at http://www.bbb.org/us/storage/0/Shared\%20Documents/finalbbbs.pdf. Kellogg's limits its use of child-directed licensed characters on the front panels of its packaging and as the basis for its "food forms," to products that meet its nutrition guidelines. BETTER BUSINESS BUREAU, supra note 33, at 4 n.5.

40. Charlene Elliott, Assessing 'Fun Foods': Nutritional Content \& Analysis of Supermarket Foods Targeted at Children, 9 OBESITY REVIEWs 368 (2008); MARKETING FOOD 
The food retail environment has not improved since the initiation of the CFBAI because packaging is not included in the pledges. ${ }^{41}$ Researchers found that from 2006 to 2008, the U.S. supermarket environment has declined. Only 73 of 397 foods (18.4\%) assessed in one study met IOM standards of healthy; thus over $81 \%$ of the foods promoted to children were unhealthy according to these objective nutrition criteria. ${ }^{42}$ Further, $79 \%$ of all food package promotions were directed at children under twelve, with $22 \%$ directed at preschool-age children and $57 \%$ directed at children. ${ }^{43}$ From 2006 to 2008, many companies increased their use of promotional methods not covered by the CBBB pledges, for example targeting an older youth audience or tie-ins to non-media partners such as toys and games. ${ }^{44}$

A 2008 study of cereals found that those most marketed to children are the least healthy of the companies' products lines. ${ }^{45}$ Children's cereals contain $85 \%$ more sugar, $65 \%$ less fiber and $60 \%$ more sodium compared to adult cereals, but they all meet the companies' self-regulatory pledges. ${ }^{46}$ In a 2011 study of fifty-eight children's products considered "Better-for-You" by members of the CFBAI, only nine products met objective nutrient criteria. ${ }^{47}$ The study revealed that $93 \%$ of the cereals, $90 \%$ of the snacks and $75 \%$ of the beverages were high in sugar according to government nutrition standards. ${ }^{48}$ Further, of the prepared meals, approximately one-third were high in saturated fat, low in fiber, and high in sodium. ${ }^{49}$

Thus, despite the existence of the CFBAI, concerns remain because the pledges are not based on strong nutritional criteria and exclude key

TO CHILDREN \& ADOLESCENTS, supra note 13, at 1; Harris et al., supra note 4.

41. See RUDD CENTER FOR FOOD POLICY AND OBESITY, supra note 28 (for example, in 2008 , preschoolers saw 642 cereals ads, children saw 721 cereal ads and $80 \%$ of them had the worst nutrition ratings (85\% more sugar, $65 \%$ less fiber, and $60 \%$ more sodium than those advertised to adults)).

42. Harris et al., supra note 4.

43. Id. See also Elliott, supra note 36 . A study of foods targeted to children in a Canadian supermarket (excluding confectionary, soft drinks, and bakery items) found them to be $89 \%$ of poor nutritional value. Three out of four of the products targeted to children had a cartoon image on the front of the box. It is also noteworthy that $63 \%$ of all the foods targeted to children had one or more nutrition claims and $62 \%$ of the foods of poor nutritional value had one or more nutrition claims. This is problematic because the use of characters, games, colors, etc. are used to attract children to the products while the nutrition claims are used to either attract or appease parents when their children request the product. See also Kathy Chapman et al., The Extent \& Nature of Food Promotion Directed to Children in Australian Supermarkets, 21 HEALTH PROMOTION INT'L 339 (2006), available at $\mathrm{http} / /$ heapro.oxfordjournals.org/content/21/4/331.full.pdf $+\mathrm{html}$. For seven food categories in Australian supermarkets that were promoted to children (sweet biscuit, snacks, confectionary, chips/savory, cereals, dairy snacks, ice-cream), $82 \%$ were unhealthy.

44. Harris et al., supra note 4.

45. RUDD CENTER FOR FOOD POLICY AND OBESITY, supra note 28.

46. Id.

47. The Prevention Institute, Claiming Health: Front-of-Package Labeling OF CHILDREN's FOOD 6 (2011), available at http://www.preventioninstitute.org/component/ jlibrary/article/download/id-593/127.html.

48. Id.

49. Id. 
marketing venues. Since the pledges do not cover retail marketing techniques and package promotions (with two minor exceptions), they are not comprehensive enough to protect children in the retail environment. If the government believes it must step in because the CFBAI does not adequately regulate companies' marketing of unhealthy products to children, the members will have missed their opportunity to self-regulate and may be subject to regulation. 50

\section{RESEARCH ON EFFECTIVENESS OF CHILD-TARGETED PROMOTIONS}

The seminal paper on children's development as consumers is John's analysis of twenty-five years of consumer socialization research on children. ${ }^{51}$ John found that young children are attracted to perceptually salient features of marketing, regardless of whether it is relevant to the product. ${ }^{52}$ This means that young children notice immediate and readily observable perceptual features in the marketplace, such as size or color of a product. ${ }^{53}$ Children pay little attention to relevant product information and have "relatively undeveloped notions about how prices reflect the valuation of goods and services." $"$ It is not until early adolescence that youth perceive the full range of connections between product, price, and value. ${ }^{55}$

John's review of consumer research found that children under age eight "are seen as an at-risk population for being easily mislead by advertising" because those children do not understand the persuasive intent of mar-

50. Although the industries are quite different, a similar situation has evolved in tobacco retail. In a study of 3 to 6 year olds, researchers found that $90 \%$ of the six year olds correctly identified Old Joe Camel as associated with cigarettes (the same percent who recognized Mickey Mouse). Paul Fischer et al., Brand Logo Recognition by Children Aged 3 to 6 Years: Mickey Mouse and Old Joe the Camel, 266 JAMA 3145 (1991). This was at a time when tobacco advertising stated that they did not advertise to children and had ceased to advertise on television. Therefore, the children's knowledge about cigarette brands came from billboards and in-store promotions. In 1998, tobacco companies entered into the Master Settlement Agreement, agreeing to limit many marketing practices and youth access to tobacco. However, this resulted in an increase in tobacco retail marketing and promotions. Slater et al., supra note 23 . For example, in $2003,94 \%$ of all tobacco industry advertising and promotions were directed at the retail environment. Congress passed the Family Smoking Prevention and Tobacco Control Act, directing the FDA to issue regulations to address some of these practices. 21 U.S.C. § 387a-1(a)(2) (2009).

51. John, supra note 1.

52. Id. at 198. In one study, children were asked to choose a candy for their friend who likes chocolate and raisins but not peanuts and were shown cards with visual candy ingredients. Over two-thirds of the kindergartners chose the candy with the most ingredients on the card, regardless of their relevance to the request. In contrast, almost two-thirds of third grade students used one of the information requests to make the choice.

53. Id. at 187.

54. Id. at 196; see also Bridges \& Briesch, supra note 11, at 169 Table 1 ("Children are typically unaware of price promotions.").

55. Id.; see also Bridges \& Briesch, supra note 11, at 169 Table 1. 
keting. ${ }^{56}$ Although most of the research is based on television marketing to children, there has been an increase in integrated marketing and it may be difficult to tease out the effect from the diverse and numerous influences. However, the comprehensive nature of marketing makes this less pertinent. ${ }^{57}$ There is a body of research on in-store promotions and packaging reviewed below that reveals efficacy of marketing in the venue and reveals why current self-regulatory pledges that exclude the retail environment are wholly ineffective.

\section{A. In-Store Promotions}

Within the retail environment, in-store displays, ads, and promotions are used to entice shoppers to products. ${ }^{58}$ For adults and children alike, instore promotions work in two ways: either they directly promote the purchase of a product or reinforce the marketing experienced through other venues prior to entering the store.

First, product promotions directly promote purchase by influencing instore decisions and impulse purchases. ${ }^{59}$ The GMA reported that $73 \%$ of shoppers make at least one impulse purchase in the food and beverage category per shopping trip (as compared to $41 \%$ and $39 \%$ in the household and healthy/beauty categories, respectively). ${ }^{60}$ Further, checkout aisles are lucrative venues for impulse purchases; hence, some suppliers pay fees to retailers for shelf space located near checkout registers. ${ }^{61}$ In fact, the advent of self-checkout aisles had the unintended consequence for retailers of de-

56. John, supra note 1, at 190.

57. In its 2006 report, Food Marketing to Children and Youth: Threat or Opportunity, the Institute of Medicine analysis of the scientific literature led the committee to conclude that "most children ages 8 years and under do not effectively comprehend the persuasive intent of marketing messages, and most children ages 4 years and under cannot consistently discriminate between television advertising and programming." COMM. ON FOOD MKTG. AND THE DIETS OF CHILDREN AND YOUTH, supra note 27, at 9. Experts consider television marketing to these young groups to be deceptive because they cannot differentiate between commercial and non-commercial speech; this is a deceptive way to propose a commercial to them. Id. at 309.

58. GMA SAles COMM. \& BoOz \& Co., supra note 12 , at 5.

Retail promotions of tobacco and alcohol are correlated with increased youth uptake for those products. See Ellickson et al., supra note 23 (among other findings: for seventh-grade non-drinkers, exposure to in-store beer displays predicted drinking onset by grade nine); Slater et al., supra note 23 (finding that cigarette retail marketing practices increase the likelihood of smoking uptake in youth).

59. Ryan Hamilton \& Dipankar Chakravarti, Symposia Summary: New Insights in Consumer Point-of-Purchase Decision Making, 35 ADVANCES CONSUMER RES. 52 (2008).

60. Grocery MFr's. Ass'N SAles COMM., ShOPPER MARKeTINg 3.0: UnLEashing THE NeXt WaVe OF VALUE 2009.

61. Fed. Trade Comm'N, Slotting Allowances In the Retail Grocery Industry: Selected CASE StUdies IN Five Product CATEgories 57 (2003), available at http://www.ftc.gov/os/2003/11/slottingallowancerpt031114.pdf. 
creasing impulse purchases and reducing profits. ${ }^{62}$ The president of a retailconsulting firm dubbed this new system "the self-checkout diet" after reports surfaced that self-checkout decreased impulse purchases, resulting in a large decrease in food and beverage calories purchased. ${ }^{63}$

Second, retail promotions reinforce other marketing experiences through integrated marketing campaigns. The GMA explained that even when a shopper may know the type of food he or she is going to purchase, $60 \%$ of brands are selected in the store. ${ }^{64}$ This means that in-store marketing is used to "reinforce those preferences and 'close the deal' in the store."65 Promotions are integrated across marketing strategies so in-store experience supports out of store advertising techniques. For example, at home a consumer may see a commercial for a product that includes a company spokescharacter and then upon entering the retail establishment, the consumer sees the spokescharacter on the product packaging to reinforce the previous positive attributes of the product displayed on the commercial. The GMA report explained that the goal is to have all out of store marketing intersect with in-store promotions. ${ }^{66}$

The GMA found that the most effective vehicles for product purchase were on and off-shelf displays and advertising, in-store events, and sampling. ${ }^{67}$ In-store displays that have the greatest impact on sales and impulse purchases were found to be "special displays," which include end-of-aisle displays, or within-aisle displays such as cardboard platforms, bins or baskets holding the products. ${ }^{68}$ End-of-aisle displays seem to have a particularly strong impact on sales, ${ }^{69}$ and industry characterizes them as "ground zero for "in-store decision making," because they are unavoidable and thus, "the best chance of getting into the passing baskets of harried shoppers."70

62. Evan Schuman, Self-Checkout Killing Impulse Items, STOREFRONT BACKTALK (July 25, 2006), http://storefrontbacktalk.com/payment-systems/self-checkout-killingimpulse-items/.

63. Id. (When going through self-check out, purchase of "chips and salty snacks dropped 53 percent," and soda and water, dropped 50 percent. "On average, we believe that self-checkout will save somebody two-and-a-half-pounds a year.").

64. GROCERY MFR's. ASS'N SALES COMM., supra note 61.

65. Id.

66. Id. (" []$] \mathrm{n}$ order to unleash the full potential of shopper marketing, it must be integrated with other demand-generation activities all along the path to purchase.").

67. GMA SALES COMM. \& BoOZ \& Co., supra note 12, at 22.

68. J.B. Wilkinson et al., Assessing the Impact of Short-Term Supermarket Strategy Variables, 19 J. MARKETING RES. 72 (1982) (Special displays have a greater impact on sales and impulse purchases than regular or expanded shelf space and are widely used as promotional techniques.). Jeffrey Inman et al., The Interplay Among Category Characteristics, Customer Characteristics, \& Customer Activities on In-Store Decision Making, 73 J. MARKETING 19, 19-29 (2009). GMA SAles COMM. \& BoOZ \& Co., supra note 12, at 22.

69. Ana Valenzuela \& Pierre Chandon, Symposium Summary: Attentional and Inferential Effects of Point-of-Purchase Marketing, 36 ADVANCES CONSUMER RES. 100 (2009).

70. Brandon Copple, Shelf-Determination, ForBES.COM (Apr. 15, 2002), http://www.forbes.com/forbes/2002/0415/130_print.html. 
Most publicly available studies on the effect of in-store promotions focus on adults; however, GMA publications recognize children are also consumers. ${ }^{71}$ There are various promotional techniques employed to attract children to products or to keep them occupied or engaged so parents can shop. These techniques include locating child-targeted food products at their eye level, placing toys and other promotional items near the most marketed foods products, providing free food samples, erecting colorful displays or attractions with which children can interact, and having kids clubs. $^{72}$

One study found that shelf placement had a bigger impact on sales than increased shelf space and this was particularly true in the breakfast cereal category, likely "due to the important role that children play in this category."73 For in-store methods to induce children to request products, researchers found that low level shelf placement had a larger impact on children than special displays. ${ }^{74}$ The former president of Harris Teeter grocery chain explained that: "Eye level equals buy level;" thus, "slowermoving items are on the top shelves, harder to find, and thus reserved for the "destination shopper.",75

In-store methods to reach children, whether in special displays or onshelf displays, have the intended effect of influencing purchases and purchase requests by youth. Studies reveal that children make purchase requests in the retail environment by brand name of the foods most promoted to youth: breakfast cereal, snacks and, beverages. ${ }^{76}$

71. GMA \& DELoITTE, supra note 9, at 7 (Marketers and retailers "recognized that a child (the consumer) and a mother (the shopper) transition from diapers to training pants in a similar way. As the child feels he/she is 'growing up,' the mother also experiences a sense of achievement that the diaper stage is over.").

72. GROCERY MFR'S. AsS'N SALES COMM., supra note 61 (In-store sampling programs are considered "an attractive way to build trial and drive impulse purchases." Even if geared towards adult in marketing material, promotional people or those behind bakery or deli counters offer samples to children.). See also Grocers Say Best Place to Influence Consumers is in Store, Associated Press, Aug. 30, 1993, at 7 (grocers hire professional food demonstrators to offer samples, tout the product and garner customer reaction.). See also Jeff Cioletti, Super Marketing: Child's Play, SUPERMARKET BUS., July 15, 2001, at 24.

73. Xavier Dreze et al., Shelf Management and Space Elasticity, 70 J. RETAILING 301, 318 (1994).

74. Bridges \& Briesch, supra note 11, at 178.

75. HaNk Cardello, Stuffed: AN InSider's LoOK at Who's (REally) MaKing AMERICA FAT 33 (2009).

76. Mary Story \& Simone French, Food Advertising and Marketing Directed at Children and Adolescents in the U.S., INT'L J. BEHAVIORAL NUTRITION AND PHYSICAL ACTIVITY (Feb. 10, 2004), http://ijbnpa.org/content/1/1/3 (finding that children's first in-store requests are often for the brand name of the product: breakfast cereal $(47 \%)$, followed by snacks and beverages (30\%) and correspond with the products most highly marketed to youth.); COMM. ON FOOD MKTG. AND THE DIETS OF CHILDREN AND YOUTH, supra note 27, at 103-04 (In one study observing requests by children aged 3-11 years to their mothers over a 30 day period. The study found that food accounted for $55 \%$ of the total requests made, including: snack and dessert foods $(24 \%)$, candy (17\%), cereal $(7 \%)$, quick serve restaurant foods $(4 \%)$, and fruit and vegetables (3\%).). 
Marketers use promotional activities to influence children to request their parent purchase their products. ${ }^{77}$ This marketing method that encourages children to make purchase requests is referred to as the "nag factor," 78 "pester power,"79 and "kidfluence" marketing researcher explained, the "young audience does not necessarily understand the purpose of advertising and may trust messages that imply unhealthy foods are good for you.",81

The American Psychological Association's Task Force on Advertising and Children ("APA Task Force") found that marketing companies hire "people trained as child psychologists that specialize in market research on children" to apply "principles in developmental psychology" to the goal of more effectively persuading children to "influence their parents to purchase these products." effect of the influence of advertising on children's desire for products is the parent-child conflict that emerges when refusals occur in response to children's purchase-influence attempts," and this "may place strain on parentchild interaction." 83 The Task Force relied on several studies that revealed child disappointment, anger, and arguing were common responses to parental refusal for food products at the supermarket. ${ }^{84}$

The marketing literature confirms this outcome. In an oft-cited study from the Journal of Marketing, researchers observed 516 parent-child (aged three to twelve) interactions in the cereal aisle. ${ }^{85}$ They found that $66 \%$ of the time, the child initiated the cereal selection ( $46 \%$ by demand and $20 \%$ by request) and the parent agreed more than half of the time. ${ }^{86}$ However, in cases where the parent denied the request, conflict emerged $54 \%$ of the time and child unhappiness $48 \%$ of the time. ${ }^{87}$ Both conflict and unhappiness

77. Bridges \& Briesch, supra note 11 .

78. Directing the Pitch: Do Smart Marketers to Children Target Kids or their Parents?, YoUTH MARKETS ALERT (Factivia, Inc.), July 1, 1998, at 1 (discussing "targeting kids with the nag factor").

79. Grilly, Punctured Neighbour, (Oct. 21, 2004, 1:14 PM), http://grilly.blogspot.com /2004/10/text-from-bernard-matthews-trade-ad-we.html ("Over the years we have continually innovated, successfully harnessing pester power to become the true market leader.").

80. James McNeal, Tapping the Three Kids' Markets, AM. DEMOGRAPHICS, Apr. 1998, at 37-41 (Discussing the "dollar value of the 'kidfluence' market . . . About $90 \%$ of product requests made by children to a parent are by brand name."); see also Anne Sutherland \& Beth Thompson, KIDFLUENCE: THE MARKETER's GUIDE TO UNDERSTANDING AND RESEARCHING GENERATION Y--KIDS, TWEENS, AND TEENS (2003).

81. Bridges \& Briesch, supra note 11 , at 159.

82. BRIAN WilcoX ET AL., REPORT OF THE APA TASK ForCE ON ADVERTISING AND CHILDREN 20 (2004).

83. See id. at 11 .

84. See id.

85. Charles Atkin, Observation of parent-child interaction in supermarket decisionmaking, 42 J. MARKETING 41 (1978).

86. Id.

87. Id. 
occurred most in the 6 to 8 year age range. ${ }^{88}$

The commercial interest in promoting nagging likely interferes with the parent or guardian's role as the "nutritional gatekeeper." The nutritional gatekeeper is the person in the household who buys and prepares food. ${ }^{89}$ Former Executive Director for the USDA's Center for Nutrition Policy and Promotion, Dr. Brian Wansink, found that this person's purchases control approximately $72 \%$ of all of the food decisions of their children and spouse, for the better or for the worse. ${ }^{90}$

\section{B. Packaging and Packaging Promotions}

Package-based advertising is especially important for children. The product's packaging brings all other advertising and promotional efforts together in one place ${ }^{91}$ and is considered one of the "most efficient marketing tools" for reaching child and adult consumers alike. ${ }^{92}$ The packaging has been deemed to have the most impact on sales among all shopper marketing methods:

Packaging plays an integral role and has a major impact on shopper marketing. When a consumer is walking down an aisle and stumbles upon a shelf talker, floor ad or end-aisle display, it is the packaging that will often result in that first moment of truth-the purchase decision. ${ }^{93}$

Further, packaging is considered more important than traditional and new digital media by some marketers. First, packaging has "a longer shelf life" than advertising and "it will be seen by more people" because there is no other vehicle that consumers interact with on a daily basis. ${ }^{94}$ Second, because the "average consumer is bombarded with anywhere from 250 to 5,000 media messages each day," 95 it "has become most challenging to connect with your consumer through any one medium" (e.g., TV, maga-

88. Id.

89. Tara Parker-Pope, Who's Cooking? (For Health, It Matters), N.Y. TIMES. (Mar. 16, 2009), http://www.nytimes.com $/ 2009 / 03 / 17 /$ health $/ 17$ well.html?_r=2; see also $F A Q$ About the Book, MINDLESSEATING.ORG, http://mindlesseating.org/faq.php (last visited Oct. 30, 2011).

90. FAQ About the Book, supra note 96.

91. Joseph DiFranza et al., Cigarette Package Design: Opportunities for Disease Prevention, 1 TOBACCO INDUCED DISEASES 97, 97-98 (2002).

92. Russ Napolitano, Packaging Can be Your Best Investment, in SHOPPER Marketing: How to Increase Purchase Decisions at the PoInt of Sale 215, 216 (Markus Stahlberg et al., eds., 2010).

93. Id. at 221 .

94. Id. at 216-17.

95. Id. at 216 . 
zines, newspapers, billboards, internet, phones, blogs, games, etc.), so the packaging is the most important vehicle to make an impression and induce sales. ${ }^{96}$ Therefore, savvy manufacturers are encouraged to make "packaging to entertain, engage and excite" consumers. ${ }^{97}$

Researchers have explained the importance of packages' communication to promote children's attraction to the products based on their limited cognitive abilities. ${ }^{98}$ One professor of marketing explained that the age span food marketers target for their packaged food is three to seven years old. $^{99}$ This makes sense for a number of reasons. Very young children cannot read or recall brand names, so attractive features such as cartoon characters are more important to their desire for a product than other aspects of the package. ${ }^{100}$ They are also less capable of storing and retrieving information so even if they enjoy a product commercial, it may not translate into purchase behavior or requests. ${ }^{101}$ Thus, packaging stimuli directed at this young age group can be the most influential to induce desire for the product. $^{102}$

Studies reveal that promotions on and in food packaging are influential on children's purchase requests, preferences and tastes. Certain promotional techniques are particularly effective and others have yet to be studied. A review of this research follows.

\section{Licensed Characters and Company Spokescharacters}

Visual recognition of a brand is important to capture young children's interest who have seen ads for the product but have a limited ability to read or recall brand names. ${ }^{103}$ Children as young as ages two to three years can recognize familiar packaging in the stores and familiar spokescharacters on food products. ${ }^{104}$ Researchers have explained that visual recognition on

96. Id.

97. Id. at 217. See also DiFranza et al., supra note 98 (researchers within the tobacco context explained the impact and purpose of packaging as follows: "The package is the ultimate communication tool, the last step in the promotional process. The package should shape consumer expectations about the product in terms of quality and image. Packages are designed to be eye catching and attractive, to have visual impact both when seen alone, as in use, and when amassed in great quantities, as in large retail displays. When the package is displayed in the store, it is the sum of the product, the package, and the associated imagery that is purchased by the consumer.").

98. Billur Ülger, Packages with Cartoon Trade Characters Versus Advertising: An Empirical Examination of Preschoolers' Food Preferences, 15 J. FooD ProDucts MARKETING 104 (2009).

99. Dick Mizerski, Issues Concerning the Effects of Advertising on Children, 24 INT'L J. ADVERTISING 399 (2005).

100. Ülger, supra note 106.

101. Id.; see also Bridges \& Briesch, supra note 11, at 163.

102. Ülger, supra note 106.

103. Id.

104. John, supra note 1, at 189; Story \& French, supra note 81 (stating that children 
product packaging induces young children's desire for products even when they do not understand the functional benefit of the product. ${ }^{105}$ An anecdote from the book Food Fight captures this precisely: a mother recounts shopping in the supermarket with her child aged four who sees Betty Crocker's Disney Princess Fruit Snacks with Cinderella, Snow White, and the Little Mermaid on the box. The child says, "I want that." The mother asks "What is it?" and the child responds, "I don't know."106

Spokescharacters and licensed characters become important attractive features on product packaging. ${ }^{107}$ It is thus not surprising that the majority of food marketed to children has some sort of cartoon character on the front of the package. ${ }^{108}$ Very popular licensed characters adorn dozens of different types of food products. For example, SpongeBob SquarePants is on products ranging from fast food to cereal to cookies. ${ }^{109}$

Three studies, in particular, of identical food offerings to children, one bearing a licensed character and one without, revealed that the licensed character induces children to prefer the taste of the food and select that item for a snack. ${ }^{110}$ In a 2005 study by Sesame Street Workshop, researchers

first request products at about two years of age and $75 \%$ of these requests occur in the supermarket).

105. Ülger, supra note 106.

106. Kelly Brownell \& Katherine HoRgen, FoOd Fight: THE INSIDE StORY OF THE Food Industry, AMERICA's Obesity CRISIS, AND What We CAN Do AbOUT It 106-07 (2004); see also Susan Linn, Remarks in Consuming KIDs: The CoMmERCIAlization of CHILDHOOD 8 (Media Education Foundation 2008) (transcript on file with author) ("SpongeBob SquarePants was Kraft's best selling macaroni \& cheese. I personally know a five year old who told her father, in no uncertain terms, that SpongeBob SquarePants Macaroni \& Cheese tastes better than any other macaroni \& cheese. Now, how do you argue with a 5 year old about that? What do you say? You say, 'no it doesn't,' and then she says, 'yeah it does.' . . . 'Well, have you ever had SpongeBob SquarePants Macaroni \& Cheese?' 'No, but I know that it tastes better."').

107. See Michael Rich, Remarks in Consuming KiDs: THE CoMmerCialization of CHILDHOOD 8-9 (Media Education Foundation 2008) (transcript on file with author) ("Growing up is a very strenuous, difficult, and sometimes hard and scary process for children. One of the things that gives them some stability and continuity in that is their attachment to touchstones in their lives. And among those touchstones are characters: Clifford the Big Red Dog, Mickey Mouse. These are constants in their lives. These are things that they have figured out, they feel they understand, and that they feel comfortable with, and indeed, in their own way, love. When you take that, and you leverage that into saying, 'eat this food,' you are basically leveraging that very powerful emotion that the child has-that very powerful attachment-to make money.").

108. Elliott, supra note 37 ( $3 / 4$ products: cartoon on box front).

109. Press Release, Parents Beware: SpongeBob Movie Rife with Commercialism, CAMPAIGN FOR COMMERCIAL-FrEE CHILDHOOD (Nov. 16, 2004), http://www.commercialfree childhood.org/pressreleases/spongebob.htm.

110. See also Matthew Lapierre et al., Influence of Licensed Spokescharacters and Health Cues on Children's Ratings of Cereal Taste, 165 ARCHIVES PEDIATRIC \& ADOLESCENT MED. 229, 231-32 (2011) (comparing four- to six-year-olds' taste preference for cereal with or without a character, children liked the same cereal with the character but there was also a difference based on the use of a different name for the cereal); Thomas Robinson et al., Effects of Fast Food Branding on Young Children's Taste Preferences, 161(8) ARCHIVES PEDIATRIC \& ADOLESCENT MED. 792, 793-94 (2007) (demonstrating that when researchers gave sixty-three children aged three to five years identical food and beverages in 
asked children to choose between broccoli and chocolate; $22 \%$ chose the broccoli and $78 \%$ of children chose the chocolate. ${ }^{111}$ However, when the researchers paired a sticker of a popular Sesame Street character Elmo with the broccoli and an unknown character with the chocolate, $50 \%$ of the children chose each product. ${ }^{112}$ Lastly, when researchers put the Elmo sticker on the chocolate and the unknown character sticker on the broccoli, $89 \%$ chose the chocolate, and $11 \%$ chose the broccoli. ${ }^{113}$ This study indicates that popular characters attract children significantly more than no character or an unknown character. ${ }^{114}$

A 2010 study corroborated the findings above. ${ }^{115}$ Children aged four to six were presented with two identical samples of one of three different types of foods (gummy bears, graham crackers, and baby carrots), but one sample bore a sticker of one of three characters: Scooby Doo, Dora the Explorer, and Shrek. ${ }^{116}$ The children were asked to taste both samples and say which one tasted better. The majority of the children preferred the taste of the snacks across all 3 food categories that had the licensed-character on the package, with $72.5 \%$ choosing the carrots, $85 \%$ preferring the gummy bears, and $87.5 \%$ choosing the graham crackers with the licensed characters on them. ${ }^{117}$

Third, an interesting study published in 2009 with Turkish children revealed that licensed characters on product packaging had a significantly greater effect on their food preference than seeing a commercial for an almost identical product. ${ }^{118}$ Researchers divided 144 preschool, six-year-old children into two statistically equivalent groups; both watched approximately 50 minutes of Bugs Bunny cartoons with the treatment group also viewing 8 commercials inserted between episodes for Chocolate Wafer "B." (The commercials were humorous, dynamic and contained child actors. ${ }^{119}$ )

branded McDonald's packaging or in plain packaging, the study subjects significantly preferred the taste of the food and beverages in the branded packaging, including carrots, which McDonald's did not offer at the time of the study).

111. Press Release, "If Elmo Eats Broccoli, Will Kids Eat it Too?" Atkins Foundation Grant to Fund Further Research, SESAME WORKSHOP (Sept. 20, 2005), http://archive. sesameworkshop.org/aboutus/inside press.php?contentId=15092302; see also JENNIFER KOTLER, HEALTHY HABITS FOR LIFE: A GREAT START TO A LIFETIME OF GoOd HEALTH (2007).

112. "If Elmo Eats Broccoli, Will Kids Eat it Too?", supra note 120; see also KoTLER, supra note 120.

113. KOTLER, supra note 120.

114. A similar result was seen when comparing the preferences for banana and grapes. See KOTLER, supra note 120; but see Lapierre, supra note 119, at 229-34. In this study of 80 four-to-six-year-olds' subjective taste of cereal from a box bearing a licensed character or no character, only six children did not recognize the character but this did not influence their taste assessment. Children who saw the character liked the cereal more than those without the character on it.

115. Christina A. Roberto et al., Influence of Licensed Characters on Children's Taste and Snack Preferences, 126 PEDIATRICs 88, 88 (2010).

116. Id. at 90.

117. Id. at 91 .

118. Ülger, supra note 106.

119. Id. at 110-111. 
After the viewing, both groups were asked to choose between Chocolate Wafer "B" that has a plain red package or Chocolate Wafer " $A$ " that had a Disney cartoon character on the red package. The majority of both groups (control group/no commercials $68 \%$; treatment group/with commercials $78 \%$ ) chose the chocolate wafer with the cartoon character on it. ${ }^{120}$

The majority of the research is on licensed characters, but company spokescharacters similarly attract children to the product. Company spokescharacters have also been shown to produce favorable brand attitudes and increase brand awareness among children. ${ }^{121}$ Marketing researchers found that the most effective marketing campaigns involve spokescharacters and that spokescharacters are more important than verbal communications in advertising campaigns to promote brand recall and favorable brand attitudes. ${ }^{122}$ Industry research makes no distinction among characters that appeal to young children or differentiate among different types of characters to induce the "nag factor."

Spokescharacters can either reflect their brand attributes or not. The classic example is Snuggle Bear is the spokescharacter for Snuggle Fabric Softener and his very being suggests softness. In the food context, Buzz, the Honey Nut Cheerio bee, references honey. Conversely, Tony the Tiger does not have any basic relevance to the sugar coated corn flakes cereal, Frosted Flakes. ${ }^{124}$ The latter type of spokescharacters have developed relevancy to the product over time and through advertisements. ${ }^{125}$ But even perceptually relevant spokescharacters need to develop meaning over time or though integrated marketing campaigns. For example, the Energizer Bunny was not immediately recognizable as a figure for the Energizer brand of batteries as opposed to a competitor's batteries. ${ }^{126}$ Because the company's research found that consumers did not recall which battery brand was associated with the bunny, Energizer introduced the bunny onto its product packaging and the association stuck. ${ }^{127}$

\section{Other Package Promotion Techniques}

The use of characters is the most studied feature of products intended

120. Id. at $111-112$.

121. Judith A. Garretson \& Scot Burton. The Role of Spokeschracters as Advertisement and Package Cues in Integrated Marketing Communications 69 J. OF MARKETING 118, 118 (2005). See also MARKETING FOOD TO CHILDREN AND ADOLESCENTS, supra note 13.

122. Garretson \& Burton, supra note 130 , at 127.

123. See Bridges \& Briesch, supra note 11, at 158-59.

124. Garretson \& Burton, supra note 130, at 118-19.

125. Tony the Tiger first appeared on cereal boxes in 1958 and now he is a well known figure for the cereal. See Company History, KeLLOGG's, http://investor.kelloggs.com /history.cfm (last visited Mar. 19, 2012).

126. Garretson \& Burton, supra note 130 .

127. Id. 
for children; however, research has shown that other tactics also have an effect. Premiums have been shown to increase short-term sales of products when children desire the item over the associated food and can also elevate the image of that brand in children's minds. ${ }^{128}$ In a marketing observational study of parent-child interactions in the cereal aisle, researchers found that $9 \%$ of the children ( $6 \%$ of $3-5$ year olds, $8 \%$ of $6-8$ year olds and $11 \%$ of 9 12 year olds) explicitly identified the premium as the primary reason for the cereal selection. ${ }^{129}$ If parents refused, these children expressed "marginally more unhappiness" than children who were not premium-oriented. ${ }^{130}$

By preschool, children can recall brand names if they are "associated with salient visual cues such as colors, pictures, or cartoon characters." For young children, these visual cues are needed to induce brand memory and recognition. Older children are able to recognize that a brand name is a distinct aspect of the product packaging. ${ }^{132}$ Marketing research explains that these older children's attitudes to a brand "is of the utmost importance" to measure the effectiveness of advertising because "marketers of very similar products are constantly approaching children with sales messages that are distinguishable only by their brand." ${ }^{.133}$ In the school food context, food service directors note that introducing a brand name food item has measurable success for inducing purchase, but when children did not recognize the brand name, it functions like a generic brand and then they focused on the actual qualities of the product, i.e., how good it tasted. ${ }^{134}$

Little research on the use of other promotional techniques such as colors or design is publicly available in the food context. It is clear that food companies use color to attract children, such as the case of Heinz EZ Squirt Ketchup, which came in colors such as green and purple. ${ }^{135}$ Reportedly, the

128. Story \& French, supra note 81 , at 10.

129. Atkin, supra note 93 , at 44 .

130. Id. at 43 .

131. John, supra note 1.

132. Gwen B. Achenreiner \& Deborah R. John, The Meaning of Brand Names to Children: A Developmental Investigation, 13 J. CONSUMER PSYCHOLOGY 205, 207 (2003).

133. Claude Pecheux \& Christian Derbaix, Children and Attitude Toward the Brand: A New Measurement Scale, J. ADVERTISING RES., July-Aug. 1999, at 19.

134. Michael Buzalka, This Brand is Your Brand, This Brand is My Brand: How Onsite Foodservice Operators Leverage the Retail Brand Equity of Major Food Manufacturers, 39 Food MGMT. 24, 33 (2004). In the tobacco context, studies of Australian and New Zealand youths revealed that American branded tobacco packaging generated positive imagery without additional promotional communications but generic packaging was considered unattractive, not "cool," and undesirable to purchase or carry around. See DiFranza et al., supra note 98, at 97 (citing Paul C. Beede \& Robert W. Lawson, Brand Image Attraction: The Promotional Impact of Cigarette Packaging, 18 N. Z. Fam. Physician 175, 175 (1991)); Centre for Behavioral Research in Cancer, Anti-Cancer Council of Victoria, Health Warnings and Content Labeling on Tobacco Products (1992) (Adolescents' reactions to cigarette packs modified to increase extent and impact of health warnings); Paul C. Beede \& Robert W. Lawson, The Effect of Plain Packages on Perception of Cigarette Health Warnings, 106 Public Health 315, 315 (1992).

135. Bridges \& Briesch, supra note 11 , at 163. 
"stores couldn't keep the bottles stocked, so the company followed up with coloured Ore-Ida fries, and Kraft Macaroni \& Cheese also began to be offered in colour." "136 Further, new innovative packaging designs are emerging that have not been studied. For example, a new technology was created to make illuminated cereal products, which are powered from the shelf and printed with inductive inks to make the package illuminate. ${ }^{137}$ Another package designer created a package that can be used to play an interactive game using the box and a motion sensing technology, like Nintendo Wii. ${ }^{138}$

\section{Summary}

In sum, the food retail environment does not support healthy choices and induces children to request and think they prefer unhealthy food because of the use of characters and other promotions on packaging and throughout the store. Government regulation may be warranted to support public health and create healthy defaults in the retail environment. This is especially the case because the food retail environment is not being addressed by industry self-regulation and has been getting progressively worse from a public health perspective.

\section{Regulating IN-Store AND PACKAGE Promotions to ProteCt CHILDREN}

At the time of this writing, there are no federal, state, or local laws directly addressing the aspects of the retail environment set forth above. There are also no cases directly on point to determine how a court might consider them if challenged by food and beverage (collectively "food") retailers or manufacturers. Government entities considering adopting laws to address food packaging and retail promotions directed at children would want to avoid and succeed in any constitutional challenges brought by industry. To this end, analogies can be drawn from the case law related to other challenges for products or services deemed problematic.

Conceptually there are two types of regulations that could be ad-

136. Id.

137. Sam Grobart, C.E.S. 2011: Diamonds in the Rough, N.Y. TIMEs (Jan. 8, 2011), http://video.nytimes.com/video/2011/01/08/business/1248069538616/ces2011-diamonds-inthe-rough.html (e.g., General Mills; see video at 2:19 minutes).

138. Press Release, Dassault Systèmes, Reinventing Packaging with Interactive 3D and Transform a Box of Cereal into a New Generation Game Console, available at http://minimoys.3ds.com/presse/nestle3dvia (used by Nestle; "player's movements are detected in real time when tilting his cereal box. All children using Wiimotes or any other motion sensor material understand very quickly the benefits of interaction between the body and the virtual world. The feeling of immersion is further enhanced by the screen image blending real and virtual. The player who seems himself like in a mirror, must collect balls of light to bring the character Bétamèche out of the Minimoys world (inside the package) onto the side of the box. This is a new step in the industry of promotions."). 
vanced to protect children and further public health. The first involves restricting the marketing of certain products to children. The second would be to restrict the location within stores of certain products to create a healthier retail environment. Both types would likely provoke challenge by the industry claiming that they implicate their First Amendment rights of commercial expression. ${ }^{139}$ However, legally they would be analyzed differently because the first would be viewed as restricting commercial speech, whereas the second would be viewed as a regulation of conduct.

The First Amendment's protection for commercial speech is relevant when government attempts to restrict commercial communication intended to induce sales. ${ }^{140}$ Food product labels are generally considered commercial speech protected by the First Amendment. ${ }^{141}$ In the context of product promotion, the case law primarily addresses restrictions on commercial speech for products only legally purchasable by adults (e.g., alcohol, tobacco). ${ }^{142}$ Even in instances when the government is attempting to protect children from communication about such products, the courts analyze the restrictions based on the rights of companies to communicate with adults and the concurrent right of adults to receive such speech. ${ }^{143}$ The Supreme Court has yet to analyze a commercial speech restriction aimed at protecting children from communication directed at them about harmful products they can legally purchase. ${ }^{144}$

The regulation of conduct invokes a different line of jurisprudence and requires a differentiation between pure and expressive conduct; again, there are no cases directly on point. ${ }^{145}$ Thus, analogies must be made in order to analyze how courts may respond to such regulations.

In both contexts it may be appropriate for the government to empha-

139. See, e.g., Commonwealth Brands, Inc. v. United States, 678 F. Supp. 2d 512 (W.D. Ky. 2010) (challenging Congress' ban on the use of graphics and color on tobacco packaging under the First Amendment) affirmed in part and reversed in part by Discount Tobacco City \& Lottery, Inc. v. United States, Nos. 10-5234 \& 5235, 2012 LEXIS 5614 (6th Cir. March 19, 2012); Philip Morris USA, Inc. v. City \& County of S.F., 345 F. App'x 276 (9th Cir. 2009) (challenging government's ban on the sale of tobacco in pharmacies under the First Amendment).

140. Bd. of Trs. of the State Univ. of N.Y. v. Fox, 492 U.S. 469, 482 (1989) ("speech that proposes a commercial transaction"). See also City of Cincinnati v. Discovery Network, Inc., 507 U.S. 410, 423 (1993) (defining commercial speech "even more narrowly, by characterizing the proposal of a commercial transaction as 'the test for identifying commercial speech." (quoting Bd. of Trs. of the State Univ. of N.Y., 492 U.S. at 473-474.)).

141. See Rubin v. Coors Brewing Co., 514 U.S. 476, 481 (1995).

142. See, e.g., id.; Lorillard Tobacco Co. v. Reilly, 533 U.S. 525 (2001).

143. See, e.g., Lorillard Tobacco Co., 533 U.S. at 525.

144. But see Brown v. Entm't Merchs. Ass'n, 131 S. Ct. 2729 (2011) (striking down California law prohibiting the sale or rental of violent video games to/by minors under strict scrutiny test). None of the justices considered this a commercial speech case.

145. But see Lorillard Tobacco Co. v. Reilly, 533 U.S. 525 (2001) (applying the United States $v$. O'Brien standard to ban on self-service displays of tobacco). 
size its elevated interest in protecting children to promote public health. Outside the speech context, the Court has held that different constitutional protections and rights apply to children than to adults. ${ }^{146}$ Within the core speech context, the Court recently devalued the government's role in protecting children from harmful core speech. ${ }^{147}$ However, in the commercial context, the Court has upheld restrictions to protect adults from overreaching by commercial actors and supported federal agencies' function to enact guidelines to protect children. ${ }^{148}$

\section{A. Government's Role in the Protection of Children}

Outside of the First Amendment context, the Supreme Court has found that children have different rights than adults and that different standards apply to children. This is clear in the juvenile justice system, where the Court found that minors' lack of maturity and vulnerability supports different sentencing allowances for minors than adults. ${ }^{149}$ In the context of privacy rights, the Supreme Court recognized three justifications for concluding that "the constitutional rights of children cannot be equated with those of adults: the peculiar vulnerability of children; their inability to make critical decisions in an informed, mature manner; and the importance of the parental role in child rearing." 150 For example, children do not have rights on par with adults to express themselves in school, ${ }^{151}$ to purchase obscene materials, ${ }^{152}$ to marry, or to vote. ${ }^{153}$ However, this appreciation has not translated

146. See e.g., Roper v. Simmons, 543 U.S. 551 (2005).

147. Brown v. Entm't Merchs. Ass'n, 131 S. Ct. 2729 (2011).

148. See Part IV.A., infra.

149. In perhaps the most vital area where this has been found, the Court held that adolescents and adults cannot be treated the same in the criminal justice system due to the inherent differences in the minds of youths. Roper v. Simmons, 543 U.S. 551, 578 (2005). In the context of juvenile offenders, the Supreme Court recognized three significant differences between minors under eighteen and adults supported by scientific and sociological studies, including: (1) a "lack of maturity and an underdeveloped sense of responsibility" that "often result in impetuous and ill-considered actions and decisions;" (2) being "vulnerable or susceptible to negative influences and outside pressures, including peer pressure," resulting in or due to "less control, or less experience with control, over their own environment"; and (3) the fact that "the character of a juvenile is not as well formed as that of an adult. The personality traits of juveniles are more transitory, less fixed." Id. at 569-70. See also Graham v. Florida, 130 S. Ct. 2011 (2010) (holding the Eighth Amendment's Cruel and Unusual Punishments Clause does not permit a juvenile offender to be sentenced to life in prison without parole for a nonhomicide crime, in part due to the factors recognized in Roper $v$. Simmons).

150. Bellotti v. Baird, 443 U.S. 622, 634 (1979).

151. Hazelwood Sch. Dist. v. Kuhlmeier, 484 U.S. 260, 272 (1988).

152. Ginsberg v. New York, 390 U.S. 629, 639-40 (1968).

153. Id. at 649-650 (Stewart, J., concurring) ("[A] child-like someone in a captive audience-is not possessed of that full capacity for individual choice which is the presupposition of First Amendment guarantees. It is only upon such a premise, I should suppose, that a State may deprive children of other rights - the right to marry, for example, or the right to vote-deprivations that would be constitutionally intolerable for adults."). 
into the Supreme Court supporting wide government protections for children against potentially harmful core speech.

In the area of core expression, the Court upheld a restriction on indecent expletives directed at a general audience (children and adults) on the radio. ${ }^{154}$ Since that 1978 case, the Federal Communications Commission ("FCC") has functioned under the theory that it can restrict indecent expletives on broadcast media; however, the Supreme Court accepted certiori in a television case to resolve the question of whether the FCC's "current indecency-enforcement regime violates the First or Fifth Amendment to the United States Constitution." ${ }^{\text {I55 }}$ It is unclear if the Court will reverse direction on this topic. Either way, the Court commonly strikes down speech restrictions to protect the interests of adults in receiving the speech and the right of the speaker to reach adults. ${ }^{156}$

Historically, the Court has upheld restrictions to protect children from obscenity, which is speech depicting "sexual conduct."157 The seminal case on the topic is Ginsberg v. New York, where the Supreme Court sustained a

154. FCC v. Pacifica Found., 438 U.S. 726, 750-51 (1978).

155. FCC v. Fox Television Stations, Inc., $131 \mathrm{~S}$. Ct. 3065, 3065 (2011), from Fox Television Stations, Inc. v. FCC, 613 F.3d 317 (2d Cir. 2010) (vacating the FCC's indecency policy under the First Amendment). See also FCC v. Fox Television Stations, Inc., $129 \mathrm{~S}$. Ct. 1800, 1813 (2009) (This was not a First Amendment case but a review of agency authority to regulate; the Court accepted the argument that, "children mimic the behavior they observe-or at least the behavior that is presented to them as normal and appropriate."). It is unclear whether this rationale could hold outside the context of indecent language, but one could argue that repeating unhealthy eating behavior is more harmful than repeating "oneword indecent expletives." Id.

156. In catchy but ultimately inconsequential dicta, the Court differentiated between adults and children in the context of attorney advertising to reject governmental paternalism for adults by stating: "We reject the paternalistic assumption that the recipients of petitioner's letterhead are no more discriminating than the audience for children's television." Peel v. Att'y Registration \& Disciplinary Comm'n, 496 U.S. 91, 105 (1990). See also Ass'n of Nat'1 Advertisers v. Lungren, 44 F.3d 726, 734 (9th Cir. 1994). The latter audience is who the food companies are targeting on packaging and in stores. Perhaps a court would be swayed by the inverse reference that the audience for children's cartoons warrant paternalistic protection precisely because they are not discriminating or knowledgeable about the commercial marketplace.

157. Brown v. Entm't Merchs. Ass'n, 131 S. Ct. 2729 (2011). See, e.g., Ginsberg, 390 U.S. at 636 (upholding a state law restricting minors' access to sexually explicit material "[b]ecause of the State's exigent interest in preventing distribution to children of objectionable material, it can exercise its power to protect the health, safety, welfare and morals of its community by barring the distribution to children of books recognized to be suitable for adults."); United States v. Am. Library Ass'n, Inc., 539 U.S. 194, 215 (2003) (Kennedy, J., concurring) ("The interest in protecting young library users from material inappropriate for minors is legitimate, and even compelling."); Denver Area Educ. Telecomm. Consortium, Inc. v. FCC, 518 U.S. 727, 743 (1996) ("[T] he provision before us comes accompanied with an extremely important justification, one that this Court has often found compelling - the need to protect children from exposure to patently offensive sex-related material."); Sable Commc'ns of Cal., Inc. v. FCC, 492 U.S. 115, 126 (1989) ("[A] compelling interest in protecting the physical and psychological well-being of minors ..... extends to shielding minors from the influence of literature that is not obscene by adult standards."). 
state ban on the sale of "girlie" magazines to minors under seventeen. 158 The Court upheld the law and found that parents "are entitled to the support of laws" to aid them in their "claim to authority in their own household to direct the rearing of their children." 159

In what seems to be a departure from the rationale in Ginsberg, the Supreme Court most recently struck down a state law prohibiting minors from buying or renting violent video games in Brown v. Entertainment Merchants Association. ${ }^{160}$ The Court considered the ban to be an unconstitutional restriction on core speech (akin to literary and artistic expression) and rejected the similarities between this law and that upheld in Ginsberg as sufficient to uphold the video game ban. ${ }^{161}$ The Court sought to distinguish between the two laws by pointing to the lack of "a longstanding tradition in this country of specially restricting children's access to depictions of violence," presumably in contrast to obscenity. ${ }^{162}$ The Court gave lip service to the state's legitimate interests in "helping concerned parents control their children."163 However, it found the law "seriously underinclusive" because it "permits a parental or avuncular veto."164 Oddly, the Court had considered this aspect of the law in Ginsberg pivotal in its constitutionality. ${ }^{165}$ The Brown Court similarly found the law to be "seriously overinclusive because it abridges the First Amendment rights of young people whose parents (and aunts and uncles) think violent video games are a harmless pastime."166

The extent the government can protect children from offensive core speech is unclear. The Brown Court diverged from the unqualified declaration in Ginsberg that the "well-being of its children is of course a subject

158. Ginsberg, 390 U.S. at 643.

159. Id. at 639. See also Bellotti v. Baird, 443 U.S. 622, 634 (1979) (protecting parents' role in childrearing); FCC v. Pacifica Found., 438 U.S. 726, 749 (1978) (quoting Ginsberg, 390 U.S. at 639-40 (supporting “"parents' claim to authority in their own household").

160. Brown, $131 \mathrm{~S}$. Ct. at 2742

161. Id. at 2735. California modeled its statute after the law upheld in Ginsberg. Id. The majority found California could not show a "direct causal link between violent video games and harm to minors." Id. at 2738. Justice Breyer, dissenting, came to the opposite conclusion. Id. at 2770 . Justice Thomas' dissent found that the majority decision "does not comport with the original public understanding of the First Amendment" based on his conclusion that the "practices and beliefs of the founding generation establish that 'the freedom of speech,' as originally understood, does not include a right to speak to minors (or a right of minors to access speech) without going through the minors' parents or guardians." Id. at 2751 (quoting another source).

162. Id. at 2736 .

163. Brown v. Entm't Merchs. Ass'n, 131 S. Ct. 2729, 2741 (2011).

164. Id. at 2742 .

165. Reno v. ACLU, 521 U.S. 844, 865 (1997) (quoting Ginsberg, 390 U.S. at 639) (distinguishing the law it struck down from the law upheld in Ginsberg because "the prohibition in Ginsberg against sales to minors d[id] not bar parents who so desire[d] from purchasing the magazines for their children," among other aspects including the fact that the New York statute only applied to commercial transactions).

166. Brown, 131 S. Ct. at 2742. 
within the State's constitutional power to regulate."167 Although the Brown majority relied on the historical disapproval of depictions of sexual conduct as a rationale for differentiating between obscenity and violence, it does not seem to be sufficient to justify the recent holding. Violent video games have depictions more likely to "corrupt the young or harm their moral development" than those at issue in Ginsberg. ${ }^{168}$ By playing the video games children are exposed to sexual depictions, where they can "rape a mother and her daughters" and "rape Native American women." In addition the children are able to "reenact the killings carried out by the perpetrators of the murders at Columbine High School and Virginia Tech," and "engage in 'ethnic cleansing' and can choose to gun down African-Americans, Latinos, or Jews." 169 The rationale is flawed, and it is now unclear whether the Court would have upheld the law at issue in Ginsberg if it was presented with such a challenge today. The best way to reconcile this outcome is to take the Court at its word that it considered violent video games akin to violent literature (like Grimm's Fairy Tales), ${ }^{170}$ and children have the equal right to access books as adults.

In the commercial context, the Supreme Court has sanctioned government restrictions on "forms of aggressive sales practices that have the potential to exert 'undue influence' over consumers."171 This occurs most frequently in the context of attorney advertising. ${ }^{172}$ Attorney advertising generally has been subject to different standards than advertising for other products and services, ${ }^{173}$ but the same underlying concern-protection of persons who are not in the position to protect themselves-is present in the

167. Ginsberg, 390 U.S. at 639.

168. Brown, $131 \mathrm{~S}$. Ct. at 2742 (discussing California's interest in passing the statute).

169. Id. at 2749-50 (Alito, J., concurring).

170. Id. at 2736 .

171. 44 Liquormart v. Rhode Island, 517 U.S. 484, 498 (1996) (citing Bates v. State Bar of Ariz., 433 U.S. 350, 366 (1977)). "When a State regulates commercial messages to protect consumers from misleading, deceptive, or aggressive sales practices, or requires the disclosure of beneficial consumer information, the purpose of its regulation is consistent with the reasons for according constitutional protection to commercial speech." Id. at 501 . See also, Paris Adult Theater v. Slaton, 413 U.S. 49, 64 (1973) ("[Securities regulations]are to protect the weak, the uninformed, the unsuspecting, and the gullible from the exercise of their own volition."); Cincinnati v. Discovery Network, 507 U.S. 410, 433 (1993) (Blackmun J., concurring) ("[Consumers have] little interest in being coerced into a purchasing decision.") (citing Ohralik v. Ohio State Bar Ass'n., 436 U.S. 447, 457 (1978)).

172. Bates v. State Bar of Ariz., 433 U.S. 350, 366 (1977); see also, Fla. Bar v. Pape, 918 So. 2d. 240, 242 (Fla. 2005).

173. See, e.g., In re Petition of Felmeister \& Isaacs, 104 N.J. 515, 536 (N.J. 1986) ("We do not believe that the Constitution requires that the rules governing attorney advertising be the same as those applicable to beer, automobiles, or casino hotels."); $c f$. Zauderer v. Office of Disciplinary Counsel of the Sup. Ct. of Ohio, 471 U.S. 626, 677 (1985) (O’Connor, J., concurring in part, concurring in the judgment in part, and dissenting in part) ("The Court's commercial speech decisions have repeatedly acknowledged that the differences between professional service and other advertised products may justify distinctive state regulation."). 
context of marketing directed at children for products that are not healthy for them. Analogies can be drawn when considering protections for children against overreaching by commercial actors.

In the attorney advertising context, the Supreme Court has upheld restrictions on commercial speech to protect adult consumers from overreaching. The Court upheld the state's ability to ban in-person solicitations by lawyers, "trained in the art of persuasion," of "vulnerable" accident victims. ${ }^{174}$ Based on this precedent, the Court also upheld a thirty-day restriction on targeted direct mail solicitations of accident victims. ${ }^{175}$ Outside the attorney advertising context, the Court agreed that the government's interest in protecting college students from commercial exploitation was substantial. ${ }^{176}$ And, the Court found that athletic recruitment letters mailed to middle school children were a "hard-sell" tactic and potentially exploitive. ${ }^{177}$

Although not yet applied to children in the commercial speech context, this recognition of the state's interest in protecting vulnerable persons from commercial exploitation is particularly important. Children are not independent and rational consumers ${ }^{178}$ who make informed and reliable decisions. ${ }^{179}$ Children have an undeveloped notion of commercial transactions. Young children cannot differentiate between commercial and factual speech and do not understand marketing's intent is to get them to desire a product. ${ }^{180}$ It is not until early adolescence that youth even perceive the full range of connections among products, price, and value. ${ }^{181}$

Governments seeking to protect children from commercial communications for unhealthy products may want to align its interests with that of the attorney advertising cases. This line of cases supports the rationale that the government can protect vulnerable population from undue commercial

174. Ohralik v. Ohio State Bar Ass'n, 436 U.S. 447, 465 (1978); but see Edenfield v. Fane, 507 U.S. 761 (1993) (declining to extend the holding of Ohralik beyond the attorney context to accountants).

175. Fla. Bar v. Went For It, Inc., 515 U.S. 618, 635 (1995); see also Alexander v. Cahill, 598 F.3d 79, 100 (2d Cir. 2010), cert. denied, 2010 U.S. LEXIS 9812 (Dec. 13, 2010).

176. Bd. of Trs. of State Univ. of N.Y. v. Fox, 492 U.S. 469, 475 (1989).

177. Tenn. Secondary Sch. v. Brentwood Acad., 551 U.S. 291, 300 (2007).

178. Robert Post, The Constitutional Status of Commercial Speech, 48 UCLA L. REV. $1,41(2000)$.

179. Ginsberg v. New York, 390 U.S. 629, 636-637 (1968) ("[W]e inquire whether it was constitutionally impermissible for New York, . . to accord minors under 17 a more restricted right than that assured to adults to judge and determine for themselves what sex material they may read or see. We conclude that we cannot say that the statute invades the area of freedom of expression constitutionally secured to minors.").

180. Soontae An \& Susannah Stern, Mitigating the Effects of Advergames on Children, $40 \mathrm{~J}$. OF ADVERTISING 43, 43 (2011) ("Results showed that none of the ad breaks helped children to clearly detect the commercial nature of the game. Also, the presence of the ad break was not linked to children's correct identification of the persuasive agent.").

181. John, supra note 1, at 196. 
influence.

Note that the courts have supported the government's interest in protecting children from the advertisement of products deemed harmful even when children are not the ultimate purchasers of the products. This has occurred in FTC cases for tobacco ${ }^{182}$ and cereal products ${ }^{183}$ where the ultimate purchaser is not necessarily the child but the advertising was considered deceptive as to them.

\section{B. Regulating the Food Retail Environment}

Based on the research outlined above, two areas emerge of particular concern: (1) the use of licensed characters and spokescharacters on packaging to influence children's request, enjoyment and perceived taste of food products, and (2) tactical placement of unhealthy products in unavoidable locations of a retail environment creating unhealthy defaults and fostering purchase requests by children. There are several options the government could consider to address packaging and the food retail environment to protect children's health: restrict the use of characters on all products intended for children as deceptive and misleading to them, restrict the use of characters on products for children that do not meet nutrition guidelines as a commercial speech restriction, or regulate the location of all such products within the retail establishment, according to nutritional guidelines and the use of a character. The restriction on the use of a character on packaging implicates commercial speech and the regulation of the location of products targets conduct within the retail environment.

Any regulation could provoke legal challenges by industry; however, there is a constitutional difference between regulating commercial speech and conduct. ${ }^{184}$ Truthful, non-deceptive labeling, marketing, and advertising are generally considered commercial speech, protected by the First Amendment. ${ }^{185}$ Government restrictions on commercial speech are subject

182. Complaint at 1, In the Matter of R.J. Reynolds Tobacco Co., No. 9285 (May 28, 1997), available at http://www.ftc.gov/os/1997/05/d9285cmp.htm (confirming the perspective that the government has the authority to protect children from products even though they are not the ultimate purchaser of the productbecause they are legally unable to purchase tobacco products).

183. ITT Continental Baking Co. Inc. v. FTC, 532 F.2d 207, 219 (2d Cir. 1976); Kellogg Co., 99 F.T.C. 8, (1982); cf. Louise A. Heslop \& Adrian B. Ryans, A Second Look at Children and the Advertising of Premiums, 6 J. OF CONSUMER RESEARCH, 414, 414 ("Children, especially very young ones, do not generally purchase products on their own. Especially when shopping for 'nontreat' items, their preferences are expressed to a parent who screens their requests.").

184. Sorrell v. IMS Health Inc., 131 S. Ct. 2653, 2664 (2011) ("It is true that restrictions on protected expression are distinct from restrictions on economic activity or, more generally, on nonexpressive conduct. It is also true that the First Amendment does not prevent restrictions directed at commerce or conduct from imposing incidental burdens on speech.").

185. Rubin v. Coors Brewing Co., 514 U.S. 476, 482 (1995); see Lorillard Tobacco 
to scrutiny under the intermediate test developed in the case, Central Hudson v. Public Service Commission of New York. ${ }^{186}$ Conversely, the First Amendment is not implicated when the government regulates pure conduct. ${ }^{187}$ In between pure conduct and speech is expressive conduct, which is conduct that has an expressive component. ${ }^{188}$ The Court has "assume[d]" that displaying products in the manner a retailer desires can be considered expressive conduct. ${ }^{189}$ Restrictions on expressive conduct are analyzed under the test created in the case of United States $v$. O'Brien, and later applied to commercial expression in Lorillard Tobacco Co. v. Reilly. ${ }^{190}$

Different levels of government are more appropriate to address these diverse aspects of the food environment. The FDA has regulatory authority over the labels on food and beverage products. ${ }^{191}$ The FDA is in the best position legally ${ }^{192}$ and practically to address the use of characters on products sold in interstate commerce. ${ }^{193}$ Conversely, the retail environment is more appropriately within the jurisdiction of state and local governments. States and locales have individual statutes on health codes, building inspections, and similar topics that can be used to enact further regulations. States and locales can enact zoning ordinances, conditional licensing, and conditional use permits to effectuate change in the retail environment.

The following legal analysis of methods to address the food retail environment is based on this division of jurisdiction over the topics. Thus, the FDA (or Congress) is best equipped to address food packaging, and thus commercial speech, and states and locales are best equipped to address the retail environment, and thus conduct. The legal analysis below attempts to flush out some of the arguments on both sides to determine which regulations would be most effective and legally defensible.

\section{FOOD AND BEVERAGE PACKAGING}

In order to address promotional practices directed at children on food packaging, the FDA could consider several options to address the use of

Co. v. Reilly, 533 U.S. 525 (2001).

186. Cent. Hudson Gas \& Elec. Corp. v. Pub. Service Comm'n of N.Y., 447 U.S. 557, 564 (1980).

187. Spence v. Wash., 418 U.S. 405,409 (1974) (discussing that activity must be "sufficiently imbued with elements of communication to fall within the scope of the First ... Amendment[].").

188. United States v. O'Brien, 391 U.S. 367, 376 (1968) (distinguishing between conduct that expresses an idea and conduct that does not).

189. Lorillard Tobacco Co., 533 U.S. at 529.

190. See Lorillard Tobacco Co. v. Reilly, 533 U.S. 525 (2001); United States v. O’Brien, 391 U.S. 367 (1968).

191. See 21 U.S.C. $\$ 343(2010)$.

192. See 21 U.S.C. $\$ 343-1(a)(2)$ (2010).

193. In 2010 the agency began an initiative to address front of package nutrition labeling icons directed at adults, but it has yet to address packaging promotions directed at children. See Notices, 75 Fed. Reg. 22602-01 (Apr. 29, 2010). 
characters on packaging. In Rubin v. Coors Brewing Co., the Supreme Court confirmed that truthful information on beer labels is considered commercial speech, ${ }^{194}$ and in Zauderer v. Office of Disciplinary Counsel, the Court found that "illustrations" on advertising directed at adults are protected to the same extent as other forms of commercial speech; restrictions on such are subject to scrutiny under the Central Hudson test. ${ }^{195}$ Although a court might strike down a prohibition on the use of images on food products for the general population, the case could be different for food products directed at and marketed to children. The following briefly reviews First Amendment jurisprudence related to restricting commercial speech and applies this intermediate test to a proposed restriction on the use of characters on packaging for food not meeting nutritional guidelines.

\section{A. Central Hudson Overview}

Courts analyze commercial speech restrictions under the Central Hudson test, ${ }^{196}$ which asks whether: (1) the expression is protected by the First Amendment, meaning that it must relate to a lawful activity and not be false, deceptive, or misleading; (2) the government asserted a substantial interest to be achieved by restricting commercial speech; (3) the regulation directly advances this interest; and (4) the restriction is not more extensive than necessary to serve this interest. ${ }^{197}$

The first inquiry under the Central Hudson test asks whether the speech in question is protected by the First Amendment, and thus, not false, deceptive or misleading. ${ }^{198}$ The First Amendment does not protect such

194. Rubin v. Coors Brewing Co., 514 U.S. 476, 481 (1995); see also Bad Frog Brewery, Inc. v. N.Y. State Liquor Auth., 134 F.3d 87, 96-97 (2d Cir. 1998).

195. Zauderer v. Office of Disciplinary Counsel of the Sup. Ct. of Ohio, 471 U.S. 626, 647 (1985).

196. Rubin v. Coors Brewing Co., 514 U.S. 476, 481-82 (1995); Lorillard Tobacco Co. v. Reilly, 533 U.S. 525 (2001) (showing industry seeks strict scrutiny over government restrictions of commercial speech; however, to date the Supreme Court has applied this intermediate test although some Justices disagree). See id. at 554-555 ("Petitioners urge us to reject the Central Hudson analysis and apply strict scrutiny. They are not the first litigants to do so. Admittedly, several Members of the Court have expressed doubts about the Central Hudson analysis and whether it should apply in particular cases. But here, as in Greater New Orleans, we see 'no need to break new ground. Central Hudson, as applied in our more recent commercial speech cases, provides an adequate basis for decision." (citations omitted)).

197. Cent. Hudson Gas \& Elec. Corp. v. Public Serv. Comm'n of N.Y., 447 U.S. 557, 564 (1980).

198. This section focuses on misleading and deceptive advertising but it is important to recognize that speech related to an unlawful activity is not protected by the First Amendment. The government may regulate or entirely ban speech proposing an illegal transaction. Vill. of Hoffman Estates v. The Flipside, 455 U.S. 489, 496 (1982) (citing Cent. Hudson Gas \& Elec. Corp., 447 U.S. at 563-564); Pittsburgh Press Co. v. Human Relations Comm'n, 413 U.S. 376, 388 (1973)). Therefore, if the government made it illegal for children to purchase certain items, such as soft drinks, the government could also ban speech directed at children 
speech and "[t]he government may ban forms of communication more likely to deceive the public than to inform it." terms misleading and deceptive interchangeably and has differentiated among three different categories of misleading speech: inherently, proven in fact, and potentially. ${ }^{200}$ The government can ban or otherwise restrict speech found to be misleading in fact or inherently misleading, but it can only require increased information disclosures or rewording of the speech if it is found to be potentially misleading; any further restriction on the latter is subject to review under the remaining three prongs of Central Hudson. ${ }^{201}$

The inherently misleading category of speech stems from the 1979 case of Friedman v. Rogers, where the Court analyzed an optometrist's challenge to a state law that prohibited the practice of optometry under an assumed, trade, or corporate name as a violation of his First Amendment rights. ${ }^{202}$ The Court held that the use of trade names is a form of commercial speech but found that because they have "no intrinsic meaning," they can cause deception. ${ }^{203}$

Although this case was decided prior to Central Hudson, it is the basis for the inherently misleading category of speech and a viable rationale to find speech to be unprotected under the first prong of Central Hudson. Lower courts tend to only apply the inherently misleading standard when the possibility of deception is "self-evident" 204 or the facts are similar to

proposing that transaction. Similarly, if the government prohibited promotional toygiveaways in food boxes or with fast-food meals, then the marketing of the same could be prohibited.

199. Cent. Hudson Gas \& Elec. Corp., 447 U.S. at 563 (citing Friedman v. Rogers, 440 U.S. 1, 15-16 (1979)).

200. In re R. M. J., 455 U.S. 191, 203 (1982) ("[W]hen the particular content or method of the advertising suggests that it is inherently misleading or when experience has proved that in fact such advertising is subject to abuse, the States may impose appropriate restrictions. Misleading advertising may be prohibited entirely. But the States may not place an absolute prohibition on certain types of potentially misleading information ... . if the information also may be presented in a way that is not deceptive. Thus, ... the remedy in the first instance is not necessarily a prohibition but preferably a requirement of disclaimers or explanation.").

201. Id.

202. Friedman v. Rogers, 440 U.S. 1, 4 (1979).

203. Id. at 11-14 ("A trade name conveys no information about the price and nature of the services offered by an optometrist until it acquires meaning over a period of time by associations formed in the minds of the public between the name and some standard of price or quality. Because these ill-defined associations of trade names with price and quality information can be manipulated by the users of trade names, there is a significant possibility that trade names will be used to mislead the public.").

204. N.C. State Bar v. Culbertson, 627 S.E.2d 644, 648 (N.C. Ct. App. 2006) (Where an attorney advertised that he was "published" in the Federal Law Reports, which are the official publications of Court of Appeals and contain court opinions and other court documents, the court found "the possibility of public deception is self-evident," and thus the defendant's statements were "inherently misleading."); $c f$. Zauderer v. Office of Disciplinary Counsel, 471 U.S. 626, 652-53 (1985) ("When the possibility of deception is as self-evident as it is in this case, we need not require the State to "conduct a survey of the ... public before it [may] determine that the [advertisement] has a tendency to mislead."' (quoting Fed. Trade Comm'n v. Colgate-Palmolive Co., 380 U.S. 374, 391 (1965)); see also Bronco Wine 
that of Friedman; i.e., when they find a word to have no intrinsic meaning (for example the word "invoice" in automobile advertising). ${ }^{205}$

Conversely, evidence is necessary for the government to show that speech is actually, or proven in fact to be misleading. ${ }^{206}$ When "experience has proved that in fact such advertising is subject to abuse, the States may impose appropriate restrictions." ${ }^{\text {,207 }}$ Lower courts consistently agree that speech is "'actually misleading' only where the record contains actual evidence of deception."208

Potentially misleading speech is by definition speech that can be presented in a way that is not deceptive, so courts require such speech to be revised accordingly or allow the government to require disclosures or disclaimers to correct any potential misunderstanding. ${ }^{209}$ Thus, the government can only require more speech in this context because potentially misleading speech is protected by the First Amendment (unlike inherently and actually misleading speech). ${ }^{210}$

If a court finds the commercial speech to be truthful and not misleading or deceptive, it applies the remaining three prongs of the Central Hudson test to the speech restriction. Under prong two, courts ask whether the regulation furthers a substantial government interest. ${ }^{211}$ Courts examine the government's rationale for passing the law to determine whether the government's interest is "substantial" and the problem the law seeks to address is real. $^{212}$ In the past, the Court has recognized that the government has a

Co. v. Jolly, 29 Cal. Rptr. 3d 462, 471-481 (Cal. Ct. App. 2005) (finding of inherently misleading when company sought to use a geographic designation in its brand name that did not accurately reflect the origin of its products).

205. Joe Conte Toyota v. La. Motor Vehicle Comm'n, 24 F.3d 754, 757 (5th Cir. 1994) (citing Barry v. Arrow Pontiac, Inc., 494 A.2d 804 (N.J. 1985); see also Adams Ford Belton, Inc. v. Mo. Motor Vehicle Comm'n, 946 S.W.2d 199 (Mo. 1997) (relying on Joe Conte Toyota to find the term "invoice" to be inherently misleading).

206. Peel v. Att'y Registration \& Disciplinary Comm'n of Ill., 496 U.S. 91, 106 (1990) (rejecting the contention that the attorney's letterhead was "actually misleading," given "the complete absence of any evidence of deception in the present case.").

207. In re R. M. J., 455 U.S. 191, 203 (1982).

208. Piazza's Seafood World, LLC v. Odom, 2004 U.S. Dist. LEXIS 25991 , at $* 13$ (E.D. La. Dec. 22, 2004) (quoting Joe Conte Toyota, Inc. v. La. Motor Vehicle Comm'n, 24 F.3d 754, 756 (5th Cir. 1994) (citing Peel v. Att'y Registration \& Disciplinary Comm'n of Ill., 496 U.S. 91, 106 (1990)); see also Snell v. Engineered Systems \& Designs, 669 A.2d 13, 21-22 (Del. 1995) (finding evidence presented did not support position that the commercial speech was misleading in fact because, although survey evidence could have been persuasive, the survey presented was outdated, from a very different geographic location, and did not ask about the actual words being contested).

209. In re R. M. J., 455 U.S. at 203; see Am. Acad. of Pain Mgmt. v. Joseph, 353 F.3d 1099, 1107 (9th Cir. 2004); see also Peel v. Att'y Registration \& Disciplinary Comm'n of Ill., 496 U.S. 91, 109 (1990). Without evidence of deception, courts struggle between the inherently and potentially misleading categories, often opting for the latter.

210. In re R. M. J., 455 U.S. at 203.

211. Cent. Hudson Gas \& Elec. Corp. v. Public Serv. Comm'n of N.Y., 447 U.S. 557, 564 (1980).

212. Edenfield v. Fane, 507 U.S. 761, 768 (1993) ("[W]e must identify with care the interests the State itself asserts. Unlike rational basis review, the Central Hudson standard 
substantial interest in promoting and protecting the public health, safety, and welfare ${ }^{213}$ and "preventing commercial exploitation" of young adults. ${ }^{214}$

The third step of Central Hudson requires that the state demonstrate that its commercial speech restriction "directly and materially advances the asserted governmental interest." 215 While the Court once accepted less, it now requires the government to provide empirical evidence to support its position that the commercial speech restriction will alleviate the harms articulated by the government to a material degree. ${ }^{216}$ In Lorillard Tobacco Co. $v$. Reilly the government successfully passed the third prong by proffering several strong studies conducted by the FDA, Surgeon General, and the IOM. ${ }^{217}$ Based on this record, the Court found that the state "provided ample documentation of the problem with underage [tobacco] use" to "justify" the regulation. $^{218}$

does not permit us to supplant the precise interests put forward by the State with other suppositions. Neither will we turn away if it appears that the stated interests are not the actual interests served by the restriction.") (citation omitted). See also Sciarrino v. City of Key West, Fla., 83 F.3d 364, 367 (11th Cir. 1996) ('To find a 'substantial interest,' a court must conclude both that the interest advanced by the state is legitimate in theory, and that that interest is in remedying a problem that exists in fact (or probably would exist, but for the challenged legislation.").

213. See, e.g., Rubin v. Coors Brewing Co., 514 U.S. 476, 485 (1995) (finding the government has a significant interest in protecting the health, safety, and welfare of its citizens); see also Fla. Bar v. Went For It Inc., 515 U.S. 618, 625 (1995) ("'States have a compelling interest in the practice of professions within their boundaries, and . . as part of their power to protect the public health, safety, and other valid interests they have broad power to establish standards for licensing practitioners and regulating the practice of professions."') (quoting Goldfarb v. Va. State Bar, 421 U.S. 773, 792 (1975)); see also Sorrell v. IMS Health Inc., 131 S. Ct. 2653, 2682 (2011) (Breyer, J. dissenting) ("The protection of public health falls within the traditional scope of a State's police powers.").

214. Bd. of Trs. of State Univ. of N.Y. v. Fox, 492 U.S. 469, 475 (1989).

215. Greater New Orleans Broad. Ass'n, Inc. v. United States, 527 U.S. 173, 188 (1999).

216. Fla. Bar v. Went For It, Inc., 515 U. S. 618, 628 (1995) ("In any event, we do not read our case law to require that empirical data come to us accompanied by a surfeit of background information."). It is noteworthy that such a statement was made in the context of an attorney advertising case, which for all intents and purposes is its own line of First Amendment jurisprudence. However, the Court has since changed its tune in commercial speech cases. See, e.g., 44 Liquormart, Inc. v. Rhode Island, 517 U.S. 484, 506 (1996) (stating that it would not rely on "speculation or conjecture" to uphold a restriction on commercial speech) (quoting Edenfield v. Fane, 507 U.S. 761, 770 (1993)). The Court has since rejected this view and now requires evidence that the regulation will alleviate the harm the government seeks to rectify to a material degree. See Lorillard Tobacco Co. v. Reilly, 533 U.S. 525, 558 (2001) (Studies and reports relied on by Massachusetts were conducted by federal agencies, the Surgeon General and the nationally recognized Institute of Medicine.). See also Thompson v. W. States Med. Ctr., 535 U.S. 357 (2002). In the rare instances where the Court appears to require less evidence to support the link between the speech restriction and the harm, the Court seems to do this only because it finds that the regulation clearly fails under the fourth prong.

217. Lorillard Tobacco Co., 533 U.S. at 558.

218. Id. at 561 . The government sometimes faces difficulty under prong three when the Court is faced with a regulatory scheme that includes a commercial speech restriction. If the government includes exceptions to the regulatory scheme that are legitimate from a regulatory perspective, and would seem to assist in the fit under prong four (that the restriction is 
Part four of the Central Hudson test asks whether the restriction is "no more extensive than necessary to further the State's interest."219 In other words, the Court considers whether the regulation suppresses more speech than necessary to address the purported harm at which it is aimed. ${ }^{220}$ For example, in Lorillard Tobacco Co. v. Reilly, the state attempted to restrict outdoor billboards within 1,000 feet of schools or playgrounds, and the Court found this indicated a lack of tailoring because in some major urban areas it would result in a near-complete ban on billboard communication to adults. $^{221}$ Restrictions are also more extensive than necessary if they intrude on adults' rights to access the speech in an effort to protect children. $^{222}$

no more extensive than necessary to further the State's interest) this can cause it to fail under prong three if it does not also advance the speech restriction. For example, in Greater New Orleans Broad. Ass' $n$ v. United States, the Court struck down a statute prohibiting broadcast advertisements for gambling at private casino because the regulation exempted tribal casinos, which the Court found undermined the government's stated purpose to reduce the social costs associated with gambling. Greater New Orleans Broad. Ass'n, 527 U.S. at 191-92. Conversely, the Court may find that the regulatory regime alone would have satisfied the government's interests without the speech restriction. In Thompson v. W. States Med. Ctr., the Court struck down a commercial speech restriction that was part of a broader regulatory regime, because the majority found the rest of the regime alone was sufficient to further the government's interest. Thompson, 535 U.S. at 357. However, the four dissenting justices found the speech restriction was necessary to fulfill the purpose of the consumer protection regulation. Id. at 385-86 (Breyer, J., dissenting joined by Rehnquist, C.J., Stevens, J., Ginsburg, J.) (finding the alternatives suggested by the court not enough without the commercial speech restriction to rectify the safety problems the government sought to address). There is a lack of clarity in applying the Central Hudson test and this often appears in prongs three and four.

219. Cent. Hudson Gas \& Electric Corp. v. Pub. Serv. Comm'n of N.Y., 447 U.S. 557, 569-70 (1980).

220. One difficulty for the government in part four is to properly address the speech in question but not more extensively than necessary. The speech restrictions struck down in Lorillard Tobacco Co. v. Reilly exemplify this point. If the regulation is broad enough to be effective (e.g., the 1,000 foot rule) it can be found to be too broad and lack tailoring, but if it is narrowly tailored to address one aspect of the problem (e.g., a ban on tobacco ads under five feet high in retail establishments) it can be found to be ineffective. Lorillard Tobacco Co. v. Reilly, 533 U.S. 525, 562, 566 (2001).

221. Lorillard Tobacco. Co., 533 U.S. at 564 (striking the tobacco advertising restrictions and explaining that "the governmental interest in protecting children from harmful materials . . . does not justify an unnecessarily broad suppression of speech addressed to adults") (quoting Reno v. Am. Civil Liberties Union, 521 U.S. 844, 875 (1997)).

222. See, e.g., Butler v. Michigan, 352 U.S. 380, 384 (1957) (invalidating a Michigan statute that made it a crime to sell to the general public literature that was inappropriate for minors) (explanation from Frankfurter, J.) ("The incidence of this enactment is to reduce the adult population of Michigan to reading only what is fit for children .... Surely, this is to burn the house to roast the pig."); see also Bolger v. Youngs Drug Prods. Corp., 463 U.S. 60, 73,75 (1983) ("The level of discourse reaching a mailbox simply cannot be limited to that which would be suitable for a sandbox .... [T] [he justifications offered by the Government are insufficient to warrant the sweeping prohibition on the mailing of unsolicited contraceptive advertisements."); Sable Comm'ns of Cal., Inc. v. FCC, 492 U.S. 115 (1989) (invalidating the Communications Act "dial-a-porn" provision that denied adult access to telephone messages which were indecent but not obscene because it far exceeded that which was necessary to limit access of minors to such messages. The court notes that it was technologically possible to prevent minors from accessing the calls while still permitting adult access). 
Under prong four, the Court also considers whether the regulating body considered alternative regulations that do not implicate speech. ${ }^{223}$ The Court is particularly likely to strike down a speech restriction under prong four when non-speech-related means of accomplishing the government's objective exist. ${ }^{224}$ In Rubin v. Coors Brewing Co., the Court invalidated a law prohibiting beer labels from displaying alcohol content, basing its ruling in part, on the existence of several alternatives that did not impinge on speech, such as directly limiting the alcohol content of beer. ${ }^{225}$

It is unclear how effective the alternatives must be in comparison to the challenged regulation. ${ }^{226}$ In 44 Liquormart, Inc. v. Rhode Island, the Court considered a statute prohibiting advertisement of liquor prices, and the plurality opinion found that the regulation failed prong four because "alternative forms of regulation that would not involve any restriction on speech would be more likely to achieve the State's goal of promoting temperance." 227 However, in Sorrell v. IMS Health Inc., the majority struck down a statute as unconstitutionally restricting commercial speech despite the dissenting Justices conclusion that no "equally effective 'more limited' restriction" was proffered or would be adequate as an alternative to the state's law. ${ }^{228}$ Similarly, in Thompson v. W. States Med. Ctr., the majority struck down the speech restriction based on the availability of alternative regulations, but the dissenting Justices found that the alternatives did not address the problem the government sought to rectify and the commercial speech restriction was necessary to effectively protect the safety of consumers. ${ }^{229}$ The conclusion one can draw is that the Supreme Court will look to whether the government considered alternatives to restricting speech in or-

223. See, e.g., Greater New Orleans Broad. Ass'n v. United States, 527 U.S. 173, 17680 (1999). The government attempted to prohibit television or radio broadcasts of lottery and casino-gambling advertisements. The Court recognized that the regulation did not need to be the least restrictive available, but it found that the regulation "permit[ed] a variety of speech that poses the same risks the Government purports to fear, while banning messages unlikely to cause any harm at all" failing part four. $I d$. at 195 .

224. See, e.g., Thompson v. W. States Med. Ctr., 535 U.S. 357, 372-73 (2002).

225. Rubin v. Coors Brewing Co., 514 U.S. 476, 490-91 (1995).

226. Thompson, 535 U.S. at 385-86 (Breyer, J., dissenting joined by Rehnquist, C.J., Stevens, J., Ginsburg, J.) (finding the alternatives suggested by the court not enough to rectify the problem the government sought to address).

227. 44 Liquormart, Inc. v. Rhode Island, 517 U.S. 484, 507 (1996) (emphasis added).

228. Sorrell v. IMS Health Inc., 131 S. Ct. 2653, 2673 (2011) (Breyer, J. dissenting, joined by Kagan, J., and Ginsburg, J.). "The majority cannot point to any adequately supported, similarly effective 'more limited restriction.' Respondents' alternatives are no more helpful. Vermont has thus developed a record that sufficiently shows that its statute meaningfully furthers substantial state interests. Neither the majority nor respondents suggests any equally effective 'more limited' restriction." Id. at 2683 (citations omitted).

229. Thompson, 535 U.S. at 385 (Breyer J., dissenting joined by Rehnquist, C.J., Stevens, J., Ginsburg, J.) ("In fact, the FDA's Compliance Policy Guide, from which the Court draws its first four alternatives, specifically warned that these alternatives alone were insufficient to successfully distinguish traditional compounding from unacceptable manufacturing."). 
der to regulate harmful products. As the Court has stated: "If the First Amendment means anything, it means that regulating speech must be a last-not first-resort." 230 These alternatives often take the form of regulating "conduct."

\section{B. Government Restrictions on the Use of Characters on Products}

\section{Characters are Deceptive and Misleading Under Prong One of Central Hudson}

If the FDA seeks to restrict the use of characters on product packaging, a court would likely subject the restriction to scrutiny under the Central Hudson test. However, the government could initially argue that the use of characters to entice children is deceptive and misleading and thus, not protected by the First Amendment. ${ }^{231}$ Such a restriction on the use of characters would be aimed at addressing deceptive speech directed at children under prong one of Central Hudson.

In this context the government would rely on the evidence that the use of characters is deceptive and misleading when used to target products to children. The research indicates that the use of characters is not just simply a persuasive advertising tool, ${ }^{232}$ but rather it actually deceives children to think they prefer the food adorned with them. ${ }^{233}$

Although tailoring is not technically necessary to meet prong one on

230. Id. at 373 .

231. See Lorillard Tobacco Co. v. Reilly, 533 U.S. 525, 603 (2001) (Stevens, J., concurring in part and dissenting in part) ("I note, moreover, that the alleged 'overinclusivity' of the advertising regulations, ... . does not 'beli[e]' the claim that tobacco advertising imagery misleads children into believing that smoking is healthy, glamorous, or sophisticated[.] For purposes of summary judgment, the State conceded that the tobacco companies' advertising concerns lawful activity and is not misleading. Under the Court's disposition of the case today, the State remains free to proffer evidence that the advertising is in fact misleading."). See Va. Bd. of Pharmacy v. Va. Citizens Consumer Council, Inc., 425 U.S. 748, 771 (1976) ("[M]uch commercial speech is not provably false, or even wholly false, but only deceptive or misleading. We foresee no obstacle to a State's dealing effectively with this problem." (internal citation omitted); $c f$. Sorrell, $131 \mathrm{~S}$. Ct. at 2672 ("The State nowhere contends that detailing is false or misleading within the meaning of this Court's First Amendment precedents.").

232. Cf. Sorrell, 131 S. Ct. 2653 at 2671 ("[T] lar but disfavored product from the marketplace by prohibiting truthful, nonmisleading advertisements that contain impressive endorsements or catchy jingles.").

233. See Rich, supra note 116 ("Growing up is a very strenuous, difficult, and sometimes hard and scary process for children. One of the things that gives them some stability and continuity in that is their attachment to touchstones in their lives. And among those touchstones are characters: Clifford the Big Red Dog, Mickey Mouse. These are constants in their lives. These are things that they have figured out, they feel they understand, and that they feel comfortable with, and indeed, in their own way, love. When you take that, and you leverage that into saying, 'eat this food,' you are basically leveraging that very powerful emotion that the child has - that very powerful attachment-to make money."). 
its own, courts would likely look positively at the government's attempt to address the nutrition-related problems if that is its intent. Since judges are swayed by their own notions and consider other elements of a law, the government would be wise to include guidelines on the ban on characters on food packaging. A well-researched and reasoned restriction is also preferable in case a court does not accept this argument under prong one and the restriction becomes subject to full Central Hudson scrutiny. Therefore the restriction on the use of characters should be defined by the nutritional criterion of the food and also account for adult-only products by excluding those items only purchasable by adults (e.g., beer) from the ban.

The Court has found that it is acceptable for the government to regulate specific "advertising in one industry but not in others, because the risk of fraud (one of the characteristics of commercial speech that justifies depriving it of full First Amendment protection) is in its view greater there. ${ }^{, 234}$ Here the risk of deception is the characteristic warranting less protection for characters on food products of poor nutritional value directed at children.

If challenged in court, the government would argue that the use of characters on unhealthy food is inherently or proven in fact to be deceptive and misleading. The potentially misleading speech category does not adequately capture or address this issue because the cure for potentially misleading speech is more speech, in the form of a disclosure or disclaimer. ${ }^{235}$ This would not rectify the problem inherent with placing characters on unhealthy food because children may not be able to comprehend the meaning of a disclaimer. This is true especially in the context of packaging where a disclosure or disclaimer would have to be written words (e.g., "Hey Kids, this character is trying to sell you something!"). Many children for whom such protection is warranted cannot read and even those who can read, there is no evidence that such a statement could cure the deception or otherwise reduce the problems associated with such marketing.

Children are attracted to characters on product packaging regardless of what food is in the package or words accompany the pictures and courts have recognized that the use of characters can be deceptive and misleading to children. ${ }^{236}$ One trademark infringement case supports this idea. A federal district found that the defendant infringed the complainant's trademark based on the similarity of the depiction of a female on the two companies'

234. R.A.V. v. City of St. Paul, 505 U.S. 377, 388-89 (1992) (internal citations omitted) (citing Morales v. Trans World Airlines, Inc., 504 U.S. 374 (1992) (state regulation of airline advertising)); Ohralik v. Ohio State Bar Ass'n, 436 U.S. 447 (1978) (state regulation of lawyer advertising).

235. See An \& Stern, supra note 186, at 56 (One study of 112 girls and boys aged 8-11 tested the effects of "advertising breaks" in advergames and found the breaks did not help children detect the commercial nature of the game or identify the commercial entity's motive was to encourage them to consume the cereal promoted.).

236. John, supra note 1, at 198; BROWNELL \& HORGEN, supra note 115, at 106-107. 
labels, packages and boxes of chocolate..$^{237}$ The court emphasized that the words upon the labels and wrappers did not appeal "as strongly to the mind of the consumer as did the picture."238 The court pointed out that, "it was through the picture" that the products became "popularly known to many persons, especially to children and others who are unable to read and write." 239 Similarly, in an FTC case a company marketed vitamins with an image of Spiderman, and the Commission found this practice was unfair and deceptive because the use of characters "has the tendency and capacity . . . to take advantage of the trust relationship developed between children and the program character., 240

Several cases are informative for the government if it attempts to restrict the use of characters on food products. In Zauderer, the Supreme Court struck down a state's attempt to prohibit an attorney from using an accurate illustration of the Dalkon Shield (an intrauterine device subject to products liability lawsuits) in his advertising. ${ }^{241}$ The Court found the illustration "serves important communicative functions: it attracts the attention of the audience to the advertiser's message, and it may also serve to impart information directly." 242 It would be difficult to argue that characters on food products impart "information" to children. ${ }^{243}$ Clearly they attract consumers to the product, as does all successful marketing. ${ }^{244}$ However, this does not detract from their misleading nature on unhealthy food marketing directed at children.

Lower courts have both upheld and struck down government efforts to ban images in advertising for service and products intended for adults. Cases where courts analyze attorney advertising to adult consumers, who are considered in need of enhanced protection in that context, ${ }^{245}$ provide a

237. Walter Baker \& Co. v. Puritan Pure Food Co., 139 F. 680 (C.C.S.D.N.Y. 1905).

238. Id. at 683 .

239. Id.

240. In re Hudson Pharmaceutical Corp., 89 F.T.C. 82, *4-5 (1977) (Consent Order to stop advertising using characters) (The FTC expressed the concern that the use of characters could "induce children to take excessive amounts of vitamin supplements which may cause injury to their health."); see also Ackerman v. Coca-Cola Company, 2010 U.S. Dist. LEXIS 73156, at *16, 25-26 (July 21, 2010); Rich, supra note 116.

241. Zauderer v. Office of Disciplinary Counsel of the Sup. Ct. of Ohio, 471 U.S. 626, 644,649 (1985).

242. Id. at 647.

243. Cf. Sorrell, 131 S. Ct. 2653 at 2671-72 (2011) (discussing how the state cannot burden "information").

244. Cf. id. at 2671 ("[T] he State may not seek to remove a popular but disfavored product from the marketplace by prohibiting truthful, nonmisleading advertisements that contain impressive endorsements or catchy jingles.").

245. See, e.g., In re Felmeister \& Isaacs, 104 N.J. 515, 536 (N.J. 1986) (The New Jersey Supreme Court said: "We do not believe that the Constitution requires that the rules governing attorney advertising be the same as those applicable to beer, automobiles, or casino hotels."); $c f$. Zauderer v. Office of Disciplinary Counsel of the Sup. Ct. of Ohio, 471 U.S. 626, 677 (1985) (O'Conner, J., concurring and dissenting) ("The Court's commercial speech decisions have repeatedly acknowledged that the differences between professional services 
compelling example because children are similarly disadvantaged in the context of marketing directed at them. State supreme courts have upheld restrictions on attorney advertising using pictorial depictions such as a cartoon logo, animation, or drawings.

In one attorney advertising case, the Supreme Court of Florida found two attorneys' advertisements violated rules prohibiting "statements describing or characterizing the quality of the lawyer's services in advertisements" and requiring that "[v]isual or verbal descriptions, depictions, or portrayals of persons, things, or events must be objectively relevant to the selection of an attorney and shall not be deceptive, misleading, or manipulative. 246 The court found that the attorneys' use of a logo of the pit bull wearing a spiked collar and the prominent display of the phone number 1800-PIT-BULL were manipulative and misleading because they did not convey objectively relevant information about the attorneys' practice, but rather conveyed an image about the nature of the lawyers' litigation tactics connoting combativeness and viciousness without providing accurate and objectively verifiable factual information. ${ }^{247}$ The court found that these representations were inherently deceptive and fell outside the protections of the First Amendment. ${ }^{248}$

Courts clearly find adult consumers of attorney services in need of increased protection from misleading and deceptive speech. Even if courts would not go as far to protect adults in other contexts, children should be considered worthy of similar protection from overreaching by commercial

and other advertised products may justify distinctive state regulation.").

246. Fla. Bar v. Pape, 918 So.2d 240, 242 (Fla. 2006).

247. Id.

248. Id.; see also In re Felmeister \& Isaacs, 104 N.J. 515 (N.J. 1986) (The Supreme Court of New Jersey revised the attorney advertising rules governing professional conduct and subjected them to First Amendment scrutiny under the Central Hudson test. The rules allow lawyers to advertise services through public media but require all advertisements to be "predominantly informational" and ban "drawings, animations, dramatizations, music, or lyrics" in televised advertising. Id. at 553. The court found that the ban met the Central Hudson test because such images on television would create "undue irrational influence on consumers in their selection of counsel." Id. It further explained that, "the danger, in television advertising, of such non-rational techniques is so great that even restricting them to the point where the entire ad is 'predominantly informational' is not sufficient protection." Id. Interestingly the court distinguished the drawings in print advertising because it did not think it had the same influence. The court quoted the Iowa Supreme Court's rationale in the context of a rule banning all television advertising by attorneys: "[e]lectronic media advertising, when contrasted with printed advertising, tolerates much less deliberation by those at whom it is aimed ... . Lost is the opportunity accorded to the reader of printed advertisements to pause, to restudy, and to thoughtfully consider." (quoting Comm. on Prof'l Ethics \& Conduct v. Humphrey, 377 N.W.2d 643, 646 (lowa 1985)). The dissent believed the regulatory requirement that televised attorney advertisement of legal services must be "predominantly informational" was potentially unconstitutional, against public policy and potentially unmanageable. The dissent opined that advertising should only be restricted if it is misleading, confusing or false and agreed with the majority that a prohibition against the use of drawing, animations, dramatization, music and lyrics in print and other non-televised media would violate the First Amendment. Id. at 553-565; see also Felmeister v. Office of Attorney Ethics, Div. N.J. Admin. Office of Courts, 856 F.2d 529, 532 (3d Cir. 1988)). 
entities seeking to sell them unhealthy products.

There is also a good argument that promotional tactics directed at young children, who cannot understand their persuasive intent, are inherently misleading according to the original conception of this category of unprotected speech. ${ }^{249}$ Both licensed characters and spokescharacters are not inherently associated with the product or its attributes. For example, Spongebob Squrepants is on dozens of products ranging from fast food to cereal to cookies. ${ }^{250}$ And Tony the Tiger was not associated with cereal or Frosted Flakes until he acquired such a meaning over time through his appearance in advertisements and on product packaging. The resulting positive association between Tony and Frosted Flakes does not necessarily reflect any claim or characteristic of the product promoted, and thus the product itself can be manipulated (e.g., to be less healthy) but the positive association between the character and the brand will remain. This was the basis for the holding in Friedman v. Rogers, where the Court found that:

A trade name conveys no information about the price and nature of the services offered by an optometrist until it acquires meaning over a period of time by associations formed in the minds of the public between the name and some standard of price or quality. Because these ill-defined associations of trade names with price and quality information can be manipulated by the users of trade names, there is a significant possibility that trade names will be used to mislead the public. $^{251}$

Similarly, characters convey "no information;" and their association with a product "acquires meaning over a period of time" and "can be manipulated" to "mislead" children. 252

249. See Angela J. Campbell, Restricting the Marketing of Junk Food to Children by Product Placement and Character Selling, 39 LoY. L.A. L. REV. 447 (2006) (arguing that product placement and licensed character marketing to children is misleading and deceptive and not protected by the First Amendment).

250. CAMPAign for COMmerCIAL-FreE Childhood, supra note 119; see also Press Release, Campaign for Commercial Free Childhood, Shrek Food, http://www.commercialexploitation.org/pressreleases/shrekfood.htm; Press Release, Campaign for Commercial Free Childhood, CCFC to Health and Human Services: Fire Shrek, (Apr. 26, 2007), http://www.commercialexploitation.org/pressreleases/fireshrek.htm (Shrek has been associated with at least fifteen different categories of food for dozens of individual products, including cereal, candy, fast food and cookies.).

251. Friedman v. Rogers, 440 U.S. 1, 12-13 (1979); see also Fla. Bar v. Pape, 918 So.2d 240, 244-49 (Fla. 2006) (This was also similar to the Supreme Court of Florida's concern with the pit bull imaging in the attorney advertisements, that it conveyed manipulative and misleading connotations about the services advertised.).

252. Friedman, 440 U.S. at $12-13$. 
Characters are not "information" in and of themselves (unlike the Dalkon Shield in Zauderer). ${ }^{253}$ Children are attracted to perceptually salient features of product packaging that are not relevant to the actual product marketed. ${ }^{254}$ Thus, only after time are children able to match product spokescharacters to the product without seeing an advertisement for the actual product. Further, it is likely that young children cannot distinguish between characters they saw in cartoon programs from those in cartoon commercials when faced with the same characters on product packaging in the retail environment. ${ }^{255}$

\section{Refuting Industry Responses}

Industry would attempt to support the position that the use of characters should be protected as commercial speech and thus any restriction on their use must pass full Central Hudson scrutiny. Industry could make several arguments to advance this position: that the characters are intended for a general audience, are used to propose a commercial transaction to a child, are used to communicate with adults that the products are intended for children, or are used to appeal to adults' nostalgia of their childhood. Each argument will be addressed in turn.

First, not all characters can reasonably be said to appeal to a general audience. A licensed character such as Dora the Explorer, who is on Nick Jr. which is explicitly directed at young pre-school aged children, ${ }^{256}$ is likely intended to attract very young children to products bearing her likeness. In contrast, a character from the movie Avatar may not similarly qualify for restriction because that movie was PG-13 and thus intended for teens and adults. In order to prevent such an industry challenge, the government would want to tailor its restriction to reach the characters directed at youth. The government could use the FTC's definitions to this end.

Second, the government could argue that even if industry is attempting to propose a commercial transaction with children, it is a deceptive method since children inherently do not understand that the characters are used to

253. See Sorrell, $131 \mathrm{~S}$. Ct. at 2671 ("The defect in Vermont's law is made clear by the fact that many listeners find detailing instructive. Indeed the record demonstrates that some Vermont doctors view targeted detailing based on prescriber-identifying information as 'very helpful' because it allows detailers to shape their messages to each doctor's practice.").

254. John, supra note 1.

255. Media Bureau Action: Comment Dates Established for Campaign for a Commercial-Free Childhood Petition for a Declaratory Ruling That a Program To Be Aired by Nicktoons Violates the Children's Television Act and the FCC's Rules and Policies, 25 FCC Rcd. 13226 (2010) (Concerns over this reverse situation have been expressed to the FCC in a petition to consider whether the makers of Sketchers shoes can have a cartoon with the company's spokescharacter, Zevo-3 as the main character); see also Petition for Declaratory Ruling filed by Campaign for Commercial-Free Childhood (Sept. 13, 2010), $\mathrm{http} / / / \mathrm{www}$. commercialexploitation.org/pdf/skechersfccpetition.pdf.

256. See generally DORA THE EXPLORER, http://www.nickjr.com/dora-the-explorer/. 
manipulate their food-related requests, enjoyment, and behaviors. ${ }^{257}$ In the studies discussed above in Section III, the presence of a familiar character became unduly influential and manipulated the children's beliefs and behaviors with respect to the promoted food product. In addition, every time a child sees the character in a movie or television show, it is essentially an advertisement for the food product bearing the same character. ${ }^{258}$ This takes unfair advantage of the trust which children place on the character. ${ }^{259}$ The food product becomes an extension of the cartoon experience and thus the concern exists when a beloved character is smiling at children from the packaging of unhealthy food. Recall Barbie Cereal, a product that "cextends the fantasy:" the "doll on the-box and the shapes of the cereal carry on the dream world of Barbie. Little girls who 'play Barbie' can pretend they're sitting down to have breakfast with her."260 The entire purpose of placing a character on the package is to extend the cartoon experience into the commercial realm. ${ }^{261}$ Characters on product packaging are not akin to the Daikon Shield illustration in Zauderer ${ }^{262}$ or words (like price or alcohol content) in Virginia Pharmacy ${ }^{263}$ and Rubin v. Coors Brewing Co. ${ }^{264}$ Some children do not even know they are not real when seen on television.

Third, industry could use words on the package to communicate with adults that the products are intended for children. Industry could also advertise this fact via other media targeted to adults. Characters themselves are not informational to adults or children.

Fourth, the argument that spokescharacters appeal to adults' nostalgia

257. Roberto et al., supra note 124.

258. Campbell, supra note 253 (quoting SUSAN LINN, CoNSUMING

KIDS: THE HOSTILE TAKEOVER OF CHILD-HOOD 97 (2004)).

259. See In the Matter of Policies and Rules Concerning Children's Television Programming, 6 FCC Rcd. 5093 (1991) ("Host-selling prohibits the use of program talent or other identifiable program characteristics to deliver commercials. It is a special application of our more general policy requiring separation of program and commercial material in order to help children distinguish between the two. Host-selling also takes unfair advantage of the trust which children place in program characters. This policy would prohibit, for example, use of a cartoon character depicted in a children's program to sell a product in a commercial aired in close proximity to the program. It would not, however, as TRAC suggests, prevent an unrelated program host from selling products that are not associated with a preceding or subsequent children's program.").

260. Miller, supra note 6.

261. See, e.g., Richard Mizerski, The Relationship Between Cartoon Trade Character Recognition and Attitude Toward Product Category in Young Children, 59 J. MARKETING 58 (1995) (company spokescharacters have been shown to increase recognition and liking of the associated product by children); see also ADRIANA BARBARO \& JEREMY EARP, CONSUMING KIDS: THE COMMERCIALIZATION OF CHILDHOOD (Media Education Foundation 2008).

262. Zauderer v. Office of Disciplinary Counsel of the Sup. Ct. of Ohio, 471 U.S. 626, 648 (1985) (the government failed to present evidence of harm, "potential abuses," and that the illustrations at issue were "likely to deceive, mislead, or confuse" adult consumers).

263. Va. State Bd. of Pharmacy v. Va. Citizens Consumer Council, Inc., 425 U.S. 748 (1976).

264. Rubin v. Coors Brewing Co., 514 U.S. 476, 481 (1995); see also Bad Frog Brewery, Inc. v. N.Y. State Liquor Auth., 134 F.3d 87, 96-97 (2d Cir. 1998). 
for their youth is a circular argument because it starts out targeting children in order to appeal to nostalgia for childhood. Restricting the use of these spokescharacters on packaging would not interfere with companies' ability to market the product to adults via other media directed at the adult population.

Finally, note that the CFBAI does to apply to any company spokescharacters on packaging, and only two companies marginally restrict the use of licensed characters on their packaging. The companies are likely aware that these characters are influential and effective in attracting children to their products, mostly of very poor nutritional value. ${ }^{265}$

Since nothing like this has been litigated under prong one of Central Hudson, it is unclear how a court would rule on such an argument. The government has a good argument that such practices are inherently misleading or proven to be misleading through the evidence presented and not protected by the First Amendment. Otherwise, a court would subject the restriction to the full Central Hudson test.

\section{Character Restrictions Should Pass the Central Hudson Test}

Assuming a court did not find that the use of characters to be deceptive and misleading on child targeted products, it would analyze any restrictions under the remaining prongs of the Central Hudson test. The case law provides limited insight into how a court would rule on such a restriction; however, the government has a strong argument that a regulation restricting the use of characters based on the nutritional quality of the food should survive review under Central Hudson scrutiny under the rationale regarding regulation of the attorney advertising and similar cases. ${ }^{266}$

Most licensed characters and spokescharacters are placed on food products of poor nutritional quality. The goal would be to limit the use of spokescharacters and licensed characters to be present only on actually healthy foods, such as fresh or frozen vegetables, to prevent the exploitation of children and overreaching by commercial actors.

Assuming a court found the characters are protected commercial speech under prong one, the court would analyze the restriction under the remaining prongs of the Central Hudson test. In the context of government restrictions on food promotion to children, the government should frame its interests in terms of protecting public health, protecting children from commercial exploitation and overreaching by commercial actors, and ad-

265. See, e.g., Jennifer L. Harris et AL., YAle Rudd Center for Food Policy \& OBesity, CEREAL F.A.C.T.S.: Evaluating THE Nutrition QuAltTY AND MARKETING OF CHILDREN'S CEREALS, REPORT SUMMARY. available at http://www.cerealfacts.org/media/Cereal_FACTS_Report_Summary.pdf

266. This could be limited to product packaging (and enforced by the FDA) or expanded to include commercials (and simultaneously enforced by the FTC). 
dressing manipulated nutrition-related beliefs and behaviors of children. Because prong three of Central Hudson requires the state to show "not merely that its regulation will advance its interest, but also that it will do so 'to a material degree,",267 a court may not sustain a commercial speech regulation "if it provides only ineffective or remote support for the government's purpose.",268 These goals are actually attainable and supported by the evidence.

Under prong two, the government has a substantial interest in protecting public health, protecting children from commercial exploitation and overreaching by commercial actors, and addressing the manipulation of children's nutrition-related beliefs and behaviors. Courts recognize the government has a substantial interest in promoting and protecting the public health, safety and welfare. ${ }^{269}$ The FDA has at its core mission to protect public health. ${ }^{270}$

The government also has an interest in protecting children from overreaching by companies seeking to make a profit off of them through manipulative commercial practices. $^{271}$ In Board of Trustees v. Fox, the Court accepted as one of four government interests the interest in "preventing commercial exploitation of [college] students." cial exploitation of young children is likely more important than for college students. This is part and parcel to the government's interest in rectifying the manipulated nutrition-related beliefs and behaviors of children. This argument is not about addressing simple persuasive advertising, ${ }^{273}$ but ra-

267. 44 Liquormart, Inc. v. Rhode Island, 517 U.S. 484, 505 (1996) (quoting Edenfield v. Fane, 507 U.S. 761,771 (1980)).

268. Id. (quoting Central Hudson Gas \& Elec. Corp. v. Public Serv. Comm'n of N.Y., 447 U.S. 557, $564(1980))$.

269. See, e.g., Rubin v. Coors Brewing Co., 514 U.S. 476, 485 (1995) (finding the Government has a significant interest in protecting the health, safety, and welfare of its citizens). See also Fla. Bar v. Went For It, Inc., 515 U.S. 618, 625 (1995) ("'States have a compelling interest in the practice of professions within their boundaries, and . . a as part of their power to protect the public health, safety, and other valid interests they have broad power to establish standards for licensing practitioners and regulating the practice of professions."') (quoting Goldfarb v. Va. State Bar, 421 U.S. 773, 792 (1975)). See also Sorrell v. IMS Health Inc., 131 S. Ct. 2653, 2681 (2011) (Breyer, J., dissenting) ("The protection of public health falls within the traditional scope of a State's police powers.").

270. FDA Fundamentals, U.S. FOOD \& DRUG ADMINISTRATION (2011), http://www.fda.gov/AboutFDA/Transparency/Basics/ucm192695.htm ("FDA is responsible for protecting the public health by assuring the safety, effectiveness, and security of human and veterinary drugs, vaccines and other biological products, medical devices, our nation's food supply, cosmetics, dietary supplements, and products that give off radiation.").

271. Bd. of Tr. of the State Univ. of N.Y. v. Fox, 492 U.S. 469 (1989).

272. Id. at 475.

273. Cf. Sorrell, $131 \mathrm{~S}$. Ct. at 2671 ("[T] 'pharmaceutical marketing has a strong influence on doctors' prescribing practices.' Brief for Petitioners 49-50. This reasoning is incompatible with the First Amendment. In an attempt to reverse a disfavored trend in public opinion, a State could not ban campaigning with slogans, picketing with signs, or marching during the daytime. Likewise the State may not seek to remove a popular but disfavored product from the marketplace by prohibiting truth- 
ther rectifying the use of characters to manipulate children to believe the products taste exceptional or to induce children to nag their parents for these unhealthy food products. ${ }^{274}$ Characters are not a form of commercial information the First Amendment has traditionally been interpreted to protect. ${ }^{275}$

Under prong three, the government would need to show the restriction directly advances the interests proffered under prong two. ${ }^{276}$ The government would present the evidence reviewed above showing that characters influence children's beliefs and behaviors with respect to the food subject to such promotions. ${ }^{277}$ The evidence reveals that children prefer the taste and choose the identical product with licensed characters. Further, such characters are currently on mostly unhealthy food products. This might be considered "hard sell" tactics inappropriate for children. ${ }^{278}$

In an attorney advertising case decided prior to Central Hudson, the Court upheld a state ban on in-person direct solicitation of an attorney to accident victims, based on the potential for overreaching, invasion of privacy, and undue influence. ${ }^{279}$ In a 2007 case, Tennessee Secondary School Athletic Ass'n. v. Brentwood Academy, a coach violated the school's agreement as part of an athletic association not to recruit "impressionable middle school athletes" by sending a letter about getting involved in football early and the plurality found the association's sanctioning of the school did not violate the First Amendment. ${ }^{280}$ Although the plurality opinion did not rely on Ohralik, four justices referenced Ohralik to analyze First Amendment issues pertinent to a contractual agreement. ${ }^{281}$ The plurality

ful, nonmisleading advertisements that contain impressive endorsements or catchy jingles. That the State finds expression too persuasive does not permit it to quiet the speech or to burden its messengers.").

274. In the core speech realm, the Court recognized (but did not value) the government's interest in "helping concerned parents control their children." Brown v. Entm't Merchs. Ass'n, 131 S. Ct. 2729, 2741 (2011). In the commercial context, the government would be seeking to address in order to assist parents in their role as "nutritional gatekeepers" for the family. Bellotti v. Baird, 443 U.S. 622, 634 (1979) (recognizing "the importance of the parental role in child rearing"). It is unclear whether this argument is still viable since Brown.

275. See Sorrell, $131 \mathrm{~S}$. Ct. at 2671 ("The defect in Vermont's law is made clear by the fact that many listeners find detailing instructive. Indeed the record demonstrates that some Vermont doctors view targeted detailing based on prescriber-identifying information as 'very helpful' because it allows detailers to shape their messages to each doctor's practice.").

276. Cent. Hudson Gas \& Electric Corp. v. Pub. Serv. Comm'n of N.Y., 447 U.S. 557, 564 (1980).

277. Roberto et al., supra note 124, at 88-93.

278. See, e.g., Tenn. Secondary Sch. Athletic Ass'n v. Brentwood Acad., 551 U.S. 291, 300 (2007).

279. Ohralik v. Ohio State Bar Ass'n., 436 U.S. 447 (1978). But see Edenfield v. Fane, 507 U.S. 761 (1993) (declining to extend Ohralik outside the attorney advertising context to accountants).

280. Tenn. Secondary Sch. Athletic Ass'n v. Brentwood Acad., 551 U.S. 291, 296 (2007).

281. Id. at 299 (Stevens, J., joined by Souter, Ginsburg, Breyer, JJ.). 
still found that:

We need no empirical data to credit TSSAA's common sense conclusion that hard-sell tactics directed at middle school students could lead to exploitation, distort competition between high school teams, and foster an environment in which athletics are prized more highly than academics. ${ }^{282}$

The "hard-sell tactics" that created a concern for exploitation were only the letters addressed to the middle school students.

In Lorillard Tobacco Co. v. Reilly, the Court agreed that product advertising stimulates demand for products and that suppressing advertising may have the opposite effect. ${ }^{283}$ In that case, the government successfully presented evidence to pass prong three by submitting reports by government agencies and the IOM that established that limiting youth exposure to advertising would decrease underage use of tobacco products. ${ }^{284}$ The same type of evidence is available in the food context: the IOM report and published studies from reputable institutions and universities. The government should similarly be able to pass prong three here.

Under prong four, the government can show that the a nutritionallybased restriction on child-targeted characters that exclude adult-only products is not more extensive than necessary to serve the government's interest in public health and protecting children from manipulation and commercial exploitation. ${ }^{285}$ First, the use of nutrition and adult-only standards indicates proper tailoring, as does using the FTC definition of targeting youth to determine which foods should be subject to restriction. The regulation likewise directly addresses the harm the government seeks to rectify, without restricting speech to adults. ${ }^{286}$ By tailoring the restriction to child-oriented food, this regulation would not reduce commercial speech intended for or used by adults to make purchase decisions. Restricting characters would not be restricting any particular commercial message or commercial speech intended for adults. Manufacturers can use words on packaging to indicate that food it intended for children or communicate other information to adult consumers.

When the Court has strikes down a commercial speech restriction un-

282. Id. at 300 (emphasis added).

283. Lorillard Tobacco Co. v. Reilly, 530 U.S. 525, 557 (2001).

284. Id. at 561 .

285. Cent. Hudson Gas \& Electric Corp., 447 U.S. at 564.

286. See, e.g., Bad Frog Brewery v. N.Y. State Liquor Auth., 134 F.3d 87, 92 (2d Cir. 1998) (The court reminded the parties that other characters have been used to market beer, including the Budweiser Frogs, Spuds Mackenzie and the Bud-Ice Penguins and rejected the advertising restrictions.). 
der prong four, it often points to regulations of conduct that it deemed viable alternatives to regulating speech that the government should have considered. In this context, the Court has pointed to specific regulations of conduct available to government seeking to protect the public from harmful products, including directly banning the product, ${ }^{287}$ limiting per capita purchases, ${ }^{288}$ prohibiting the purchase by minors, ${ }^{289}$ and implementing specific restrictions on sale such as requiring harmful products to be placed in specific areas. ${ }^{290}$

Absent a politically and logistically impossible federal law banning the sale of all unhealthy food and beverages, alternative forms of regulation would not achieve the governments' interests under prong four. For example, taxation ${ }^{291}$ of food products packaged with characters would not achieve the governments' interests because manufacturers would likely pass on the cost to consumers and thus the products that induce children to have unhealthy nutrition related beliefs and behaviors would simply be more expensive, increasing the difficulty parents already face while being nagged for those products.

Education campaigns directed at adults may help parents to understand that the products are unhealthy, but this again would not diminish the impact on children who do not understand such messages. Similarly, media literacy campaigns have not shown to be effective to counteract food advertising effects for children. ${ }^{292}$ Consider that children ages two to three years can recognize familiar packages in the stores and familiar spokescharacters on food products; by the time they enter the first grade children are familiar with roughly 200 brands, ${ }^{293}$ and their food preferences are well established at this point. ${ }^{294}$ Practically, the government would not have jurisdiction to intervene until children enter public elementary school, which is well after their food preferences are established. Only older children have the capacity to understand media literacy education because children under eight years of age cannot comprehend persuasive intent, ${ }^{295}$ and even for those who can, this has not been proven effective at moderating the influence of

287. 44 Liquormart, Inc. v. Rhode Island, 517 U.S. 484, 524 (1996) (Thomas, J., concurring in part and concurring in judgment).

288. Id. at 507.

289. Lorillard Tobacco Co., 533 U.S. at 586 (Thomas, J., concurring in part and concurring in the judgment).

290. Id. at 569-70.

291. 44 Liquormart, Inc., 517 U.S. at 507.

292. Jennifer L. Harris \& John A. Bargh, The Relationship between Television Viewing and Unhealthy Eating: Implications for Children and Media Interventions, in HEALTH COMMUN. 660, 660-73 (2009).

293. Committee on Food Marketing and the Diets of ChIldRen and Youth, THREAT OR OPPORTUNITY? 103 (J. Michael McGinnis, et al. eds., 2006).

294. Harris \& Bargh, supra note 295.

295. COMMITTEE ON FOOD MARKETING AND THE DIETS OF CHILDREN AND YOUTH, supra note 299 , at 327 . 
ad exposure on product preference. ${ }^{296}$ Thus, training in the use of powers of discernment requires that youth have reached a certain developmental stage, which only occurs after their food related beliefs and behaviors are established. ${ }^{297}$

Importantly, increased nutrition knowledge by children has not led to changes in dietary behavior except to result in lower perceived taste for those foods. ${ }^{298}$ In fact in one study of children ages five to eleven, exposure to a video that explained the purpose of advertising resulted in an increase in the children's preferences for the advertised products. ${ }^{299}$ Even if media literacy actually worked, the government could not afford to match the \$1.6 billion spent by industry to market food to children. ${ }^{300}$

According to the analysis above, the FDA has a strong argument that a restriction on the use of characters on unhealthy food and beverage products should withstand scrutiny under the Central Hudson test. In this context, the Court has upheld a federal agency's ability to restrict indecent language on broadcast media and called sports recruitment letters to middle school "hard sell" tactic. Cartoon characters on product packaging may seem benevolent, but the resulting poor nutrition related beliefs and behaviors is arguably much more harmful to children than these cases indicate, and parents cannot shield children from them when shopping in the supermarket. This restriction is a potentially viable option to address the negative impact the current retail food environment has on children.

\section{Other Package Restrictions}

As indicated in the review of research above, manufacturers use other techniques to market unhealthy food products to children, but there is not the same amount of research on efficacy of these methods as the use of characters. There is no case on point but a recent case in the tobacco context will likely inform future action in this area. The federal government restricted the use of color on tobacco labeling and advertising, including depictions of the package in the advertisement but not the packages themselves, based on the theory that color is used to attract children. ${ }^{301}$ The tobacco industry challenged the regulations and the district court found that

296. Ariel Chernin, The relationship between children's knowledge of persuasive intent and persuasion: The case of televised food marketing, (Jan. 1, 2007) (dissertation, Univ. of $\mathrm{Pa}$.), available at $\mathrm{http} / /$ repository.upenn.edu/dissertations/AAI3292015/.

297. COMMITTEE ON FOOD MARKETING AND THE DIETS OF CHILDREN AND YOUTH, supra note 298 , at 327 .

298. Harris \& Bargh, supra note 298.

299. Chernin, supra note 299.

300. BROWNELL \& HORGEN, supra note 115 , at 106.

301. Family Smoking Prevention and Tobacco Control Act of 2009, Pub. L. No. 11131,123 Stat. 1776 (2009). 
the ban on the use of color was overbroad and unconstitutional. ${ }^{302}$ The Sixth Circuit affirmed this finding, explaining that the government cannot institute a "sweeping ban" on color, but rather must identify and target "only the speech necessary to effect its purposes."303 It is noteworthy that the Sixth Circuit identified as valid the tobacco companies' interests in "simply showing the package" in their advertising in order to "reinforce consumer preference," let customers "know their preferred brand" 304 is sold at a particular retailer, and grab consumer attention "in a crowded marketplace." 305

Lastly, addressing the practice of using premiums for unhealthy food is one additional practice that might be accessible to the FDA. This would not be an alternative to regulating the use of characters, but rather a potential regulation of conduct. The FDA could restrict the ability of manufacturers to include premiums with foods not meeting strong nutritional guidelines. This would only address one part of the problem with unhealthy food targeted to children (and in essence only for one type of product because over $90 \%$ of the premiums were used for cereal promotion). This regulation could perhaps be part and parcel of a restriction on the use of characters on products. Federal courts that have analyzed restrictions on the use of premiums in tobacco products have found that they survive Central Hudson review or have found them to be valid regulations of conduct. ${ }^{306}$ In

302. Commonwealth Tobacco v. United States, 678 F. Supp. 2 d 512 (W.D. Ky. 2010 ).

303. Discount Tobacco City \& Lottery v. United States, Nos. 10-5234 \& 5235, 2012 LEXIS 5614, at *89 (6th Cir. Mar. 19, 2012).

304. The Supreme Court held that a trade name constitutes commercial speech in Friedman v. Rogers; and lower courts have found other trade, brand and corporate names to be commercial speech in subsequent cases. Friedman v. Rogers, 440 U.S. 1, 11 (1979); Piazza's Seafood World, LLC v. Odom, No. 3:02CV458(MRK), 2004 U.S. Dist. LEXIS 25991, at *7 (E.D. La. Dec. 23, 2004) ("The parties agree that a trade name constitutes commercial speech, and that regulations on commercial speech are subject to the four-part test articulated by the Supreme Court in Central Hudson Gas v. Public Service Commission, 447 U.S. 557, 65 L. Ed. 2d 341, 100 S. Ct. 2343 (1980)); Kalman v. Cortes, 723 F. Supp. 2d 766, at 792-95 (E.D. Pa. 2010). Trademarks are considered to "play a significant role in our public discourse" as is other types of commercial speech. Alex Kozinski (Ninth Circuit Judge), Trademarks Unplugged, 68 NYU L. REV. 960, 972-973 (1993). Accordingly, restrictions on their use have been analyzed under the Central Hudson test. Piazza's Seafood World, LLC v. Odom, No. 04-690, 2004 U.S. Dist. LEXIS 25991, at *7 (E.D. La. Dec. 23, 2004); see also Bad Frog Brewery v. N.Y. State Liquor Auth., 134 F.3d 87, $96-97$ (1998) ("Bad Frog's label attempts to function, like a trademark, to identify the source of the product."). The Supreme Court also held that color alone can meet the standard for trademark protection. Qualitex Co. v. Jacobson Products Co., 514 U.S. 159, 166 (1995) (green-gold dry cleaning press pads); see also Capri Sun Inc. v. Beverage Pouch Systems Inc., No. $97 \mathrm{C}$ 1961, 2000 U.S. Dist. LEXIS 10966, at *2, *14 n.3 (N.D. Ill. July 24, 2000) (blue pouch packaging); Hershey Foods Corp. v. Mars, Inc., 998 F. Supp. 500, 507 (M.D. Pa. 1998) (orange trade dress).

305. Discount Tobacco City \& Lottery v. United States, Nos. 10-5234 \& 5235, 2012 LEXIS 5614, at *88 (6th Cir. Mar. 19, 2012).

306. Commonwealth Tobacco, 678 F. Supp. 2d at 538-539. (finding companies do not "have any First Amendment interest in rewarding purchasers of tobacco products with "prizes, such as MP3 players, digital cameras, and prepaid gift cards"'); but see Discount Tobacco City \& Lottery, Inc. v. United States, Nos. 10-5234 \& 5235, 2012 LEXIS 5614, at *73-74 
the area of food, there is research indicating that premium offers induce purchase requests by children. There is a good argument that a restriction on the use of premiums should be analyzed as a regulation of conduct, discussed further below. ${ }^{307}$

\section{REgUlation OF IN-STORE PROMOTIONS AND PLACEMENT}

Local retail establishments are subject to the jurisdiction of state and local (hereinafter state) governments. State governments may seek to regulate the techniques directed at children in the food retail environment, including on and off shelf displays, ads, and promotions. ${ }^{308}$ If the government were to address in-store techniques, there are two ways it could address them. The government could attempt to restrict in-store advertisements or it could regulate the location of products, in-store displays, and promotions. There is little case law on restricting in-store advertisements and the latter regulations of conduct provide an alternative to regulating speech. ${ }^{309}$

\section{A. In-Store Advertising Restrictions}

In terms of framing an in-store advertising restriction, the government would need to consider appropriate and inappropriate locations. The FTC's definition of in-store advertising and promotions accounted for the height of the advertising display or promotion to verify whether it was intended to reach youth. ${ }^{310}$ The primary case relevant to restrictions on in-store advertising directed at children was based on industry challenges to a restriction determined by the height of the advertisement. In Lorillard Tobacco Co. $v$. Reilly, Massachusetts sought to prohibit the advertisement of tobacco products from being placed lower than five feet from the floor of any retail establishment located within 1000 feet of a school or playground. ${ }^{311}$ The Court considered this restriction an attempt to "regulate directly the communicative impact of indoor advertising" and found that it failed prongs

(6th Cir. March 19, 2012) (finding this provision is subject to and survives Central Hudson scrutiny).

But see, Jones v. Vilsack, 272 F.3d 1030, 1035-1036 (8th Cir. 2001) (describing a state law banning the provision of "free articles, products, commodities, gifts, or concessions in any exchange for the purchase of cigarettes or tobacco products" as a restriction on "activities" or "conduct" but finding the provision preempted by the Federal Cigarette Labeling and Advertising Act which bars states from regulating the "advertising or promotion of any cigarettes").

307. Atkin, supra note 93 , at 41.

308. GMA Sales Comm. \& Booz \& Co., Shopper Marketing 4.0: Bullding Scalable Playbooks that Drive Results 5 (Nov. 9, 2010), http://www.gmaonline.org/downloads/research-and-reports/Shopper_Marketing_4.0.pdf.

309. Thompson v. W. States Med. Ctr., 535 U.S. 357, 373 (2002).

310. MARKETING FOOD TO CHILDREN AND ADOLESCENTS: APPENDICES, supra note 14 , at B-7, B-18, B-32, C-7.

311. Lorillard Tobacco Co. v. Reilly, 533 U.S. 525, 566 (2001) (quoting 940 MASS. CODE REGS. $\S \S 21.04(5)(b), 22.06(5)(b)(2000))$. 
three and four of the Central Hudson test. ${ }^{312}$ The Court did not explicitly analyze the restriction according to each prong of the test but found that the five foot rule did "not seem to advance" the goal of preventing minors from using tobacco products because "[n]ot all children are less than 5 feet tall, and those who are ... [certainly have the ability to] look up and take in their surroundings." ${ }^{313}$ The Court's rationale is broadly stated and focuses on lack of efficacy of the speech restriction.

Since Lorillard addressed in-store advertisements for products children are not legally allowed to purchase, the Court's rationale, while broadly stated, may not directly apply to targeted marketing of unhealthy products to children. If the government had attempted to ban the advertisement of products purchasable by adults and children, such as candy below five feet, industry would argue that the rationale would equally apply. ${ }^{314}$ But there are substantial differences. Although as a product, tobacco is generally considered a greater threat to public health than unhealthy food, tobacco ads are presumably directed at adults. In-store food

312. Id. at 566-67 (Interestingly, in Lorillard, the Supreme Court compared the tobacco ads to displays of candy: "Massachusetts may wish to target tobacco advertisements and displays that entice children, much like floor-level candy displays in a convenience store, but the blanket height restriction does not constitute a reasonable fit with that goal." The problem with the Court's analogy is that floor level candy displays are not advertising in and of themselves. Rather, they are a sales mechanism. Regulations of sales practices within retail establishments are not analyzed under Central Hudson, as indicated later in the Lorillard opinion and discussed below. But perhaps the thrust of the statement was to note is that the Court was referring to the enticement of the candy display and compared it to the enticement of tobacco advertising. The real issue is that even if we know that the a colorful sign three feet from the floor advertising candy appeals to children more than adults, candy is an item that adults purchase and consume and for which adults have a First Amendment right to receive marketing messages. The issue changes, however, when analyzing a restriction on the location of the candy display itself or a restriction on the use of specific marketing techniques on the display such as the use of a licensed character geared towards young consumers.).

313. Lorillard Tobacco Co., 533 U.S. at 566.

314. See id. at 588-89 (Thomas, J., concurring in part and concurring in the judgment). (Justice Thomas compared tobacco with fast food and explained that fast food companies overtly target children with their advertising, there is evidence that they have been successful in changing children's eating behavior, and this is a problem due to both childhood obesity and the fact that eating preferences formed in childhood persist into adulthood. However, he would find that restrictions on fast food advertising to children should similarly fail First Amendment scrutiny. He found that tobacco companies "are no different from the purveyors of other harmful products, or the advocates of harmful ideas. When the State seeks to silence them, they are all entitled to the protection of the First Amendment."); but see Brown v. Entm't Merchs. Ass'n, 131 S. Ct. 2729, 2752 (2011) (Thomas, J., dissenting) ("The historical evidence shows that the founding generation believed parents had absolute authority over their minor children and expected parents to use that authority to direct the proper development of their children. It would be absurd to suggest that such a society understood 'the freedom of speech' to include a right to speak to minors (or a corresponding right of minors to access speech) without going through the minors' parents. The founding generation would not have considered it an abridgment of 'the freedom of speech' to support parental authority by restricting speech that bypasses minors' parents."). 
advertising often consists of characters targeted only to young children, setting it apart from the tobacco ads. If the government attempted to ban such an advertisement, food retailers and manufacturers would likely argue that it interferes with their ability to communicate with adults (and children) and should fail under the rationale stated in Lorillard.

The government can make the same arguments as under Section III, above in relation to product packaging about in-store advertisements directed at children. State governments have an interest in protecting children from overreaching by commercial marketers who use "hard sell" tactics to induce the request and purchase of unhealthy products by children. The difference between this argument in relation to in-store advertising and packaging is that package promotions have been studied and proven successful, while there is less research on in-store advertising. Increased research on in-store advertising tactics would likely benefit state governments that wish to regulate this aspect of the retail environment. In addition, there is little case law on the topic of regulating in-store advertising beyond this section of the Lorillard opinion.

While this area of research develops, state governments may alternatively seek to regulate the location of products within the retail environment. The goal of such regulations would be to target conduct instead of speech. Regulations of conduct are not subject to Central Hudson analysis. Pure regulations of conduct are not subject to First Amendment scrutiny at all, and regulations of conduct with an expressive component are subject to a different intermediate test developed in the case of United States $v$. $O$ 'Brien. Although both are considered intermediate tests, O'Brien has proven easier to pass than Central Hudson because the First Amendment implications are diminished when the government regulates conduct instead of speech. ${ }^{315}$

\section{B. In-Store Regulations of Conduct}

In order to address the most problematic aspects of the retail environment directed at children, there are two regulations of conduct state governments could implement. First, the government could regulate the location of products not meeting nutritional guidelines, and second, it could regulate the location of products bearing characters on the packaging and not meeting nutritional guidelines.

\section{Non-expressive and Expressive Conduct}

Government regulation of the sale of goods differs from the regulation

315. Compare Lorillard Tobacco Co. v. Reilly, 533 U.S. 525, 569 (2001), with 44 Liquormart, Inc. v. Rhode Island, 517 U.S. 484, 512 (1996). 
of accurate information about those goods. ${ }^{316}$ A plurality of the Court has stated that:

The text of the First Amendment makes clear that the Constitution presumes that attempts to regulate speech are more dangerous than attempts to regulate conduct . . . . As a result, the First Amendment directs that government may not suppress speech as easily as it may suppress conduct, and that speech restrictions cannot be treated as simply another means that the government may use to achieve its ends. ${ }^{317}$

This has proven to be true in practice.

The Court has confirmed that the regulation of conduct with no expressive component does not implicate the First Amendment. ${ }^{318}$ If it is necessary to explain the meaning of the conduct with speech it would not be considered expressive. ${ }^{319}$ Pure conduct is not protected by the First Amendment, and lower courts have found that the basic sale of products does not constitute expressive activity. ${ }^{320}$

However, the regulation of conduct with an expressive component subjects the restriction to First Amendment scrutiny under United States $v$. $O^{\prime}$ Brien. ${ }^{321}$ A clear cut example of expressive conduct is burning a flag to protest war. $^{322}$

In Lorillard Tobacco Co. v. Reilly, the Supreme Court analyzed Massachusetts' regulation that banned self-service displays of tobacco and required that "tobacco products be placed out of the reach of all consumers in

316. 44 Liquormart, Inc., 517 U.S. at 512 (plurality opinion).

317. Id. (plurality opinion).

318. Sorrell v. IMS Health Inc., 131 S. Ct. 2653, 2664 (2011) ("It is also true that the First Amendment does not prevent restrictions directed at commerce or conduct from imposing incidental burdens on speech."); see also Arcara v. Cloud Books, Inc., 478 U.S. 697, 706-707 (1986) ("[W]e have subjected such restrictions to scrutiny only where it was conduct with a significant expressive element that drew the legal remedy in the first place, as in $O$ 'Brien, or where a statute based on a nonexpressive activity has the inevitable effect of singling out those engaged in expressive activity, as in Minneapolis Star. This case involves neither situation, and we conclude the First Amendment is not implicated by the enforcement of a public health regulation of general application against the physical premises in which respondents happen to sell books.").

319. See Rumsfeld v. Forum for Academic and Institutional Rights, Inc., 547 U.S. 47, 66 (2006).

320. See Philip Morris, USA, Inc. v. City \& Cnty. of S.F., No. 08-17649, 345 Fed. Appx. 276, 2009 U.S. App. LEXIS 20142, 2009 WL 2873765, at *1 (9th Cir. Sept. 9, 2009) ('Selling cigarettes isn't [protected activity] because it doesn't involve conduct with a 'significant expressive element."') (quoting Arcara v. Cloud Books, Inc., 478 U.S. 697, 701-02, $706(1986))$.

321. Lorillard Tobacco Co. v. Reilly, 533 U.S. 525, 569-70 (2001).

322. Spence v. Washington, 418 U.S. 405 (1974). 
a location accessible only to salespersons."323 The purpose of the regulation was to minimize customer access without proper age verification to prevent minors from obtaining tobacco products. The Court found that this was not a regulation of speech because "Massachusetts' sales practices provisions regulate conduct that may have a communicative component, but Massachusetts seeks to regulate the placement of tobacco products for reasons unrelated to the communication of ideas." 324 However, the Court "[a]ssum[ed] that petitioners have a cognizable speech interest in a particular means of displaying their products," and thus analyzed the restriction under the framework for restrictions on expressive conduct developed in United States $v$. O'Brien. ${ }^{325}$ The Court found that the regulations withstood First Amendment scrutiny. ${ }^{326}$ It is unclear whether Massachusetts challenged the Court's assumption that the tobacco companies had a speech interest in displaying their products, but it may be worth challenging this assumption in subsequent cases where the government attempts to regulate the location of products within retail establishments. ${ }^{327}$ Lorillard was the $^{2}$ first time the Court explicitly applied the O'Brien test to commercial conduct.

In the test developed in United States v. O'Brien, the Court laid out the inquiry to analyze government regulations that are unrelated to the suppression of expression but incidentally impinge on speech interests. In this context, the Court held that it would find a government regulation is sufficiently justified:

if it is within the constitutional power of the Government; if it furthers an important or substantial governmental interest; if the governmental interest is unrelated to the suppression of free expression; and if the incidental restriction on alleged First Amendment freedoms is no greater than is essential to the further-

323. Lorillard Tobacco Co., 533 U.S. at 567 (citing 940 Code of Mass. Regs. $\S \S$ $21.04(2)(c)-(d), 22.06(2)(c)-(d)(2000))$.

324. Id. at 570 (internal citations omitted).

325. Id. at 569 .

326. Id. This was the first time since the advent of the Central Hudson test that the Court expressly applied a standard other than Central Hudson to commercial expression. In Hoffman Estates v. Flipside, the Court found the regulation of commercial conduct (i.e., product location within a store) constitutional. It simply remarked that the conduct fell out of the purview of Central Hudson, but did not cite O'Brien or the time, place, and manner test in its stead. See Hoffman Estates v. Flipside, 455 U.S. 489, 496 (1982).

327. Cf. Sorrell, $131 \mathrm{~S}$. Ct. at 2664 ("It is true that restrictions on protected expression are distinct from restrictions on economic activity or, more generally, on nonexpressive conduct. It is also true that the First Amendment does not prevent restrictions directed at commerce or conduct from imposing incidental burdens on speech.”). 
ance of that interest. $^{328}$

Part one of the $O^{\prime} B r i e n$ inquiry asks whether the enactment of the regulation is within the constitutional powers of the government entity. The ability of states and their political subdivisions to enact public health regulations stems from the traditional police powers allocated to them. ${ }^{329}$ This "police power" is recognized in case law dating back to the early 20th century as conferring upon state and local governments the ability to enact laws to protect the public's health, safety, and welfare. ${ }^{330}$ A valid public health rationale will therefore generally pass part one of the $O$ 'Brien test and the Court has upheld this justification, explaining: "[t]he first factor of the $O$ 'Brien test is whether the government regulation is within the constitutional power of the government to enact. Here, [the city's] efforts to protect public health and safety are clearly within the city's police powers."331

Part two of the $O$ 'Brien test seeks to ascertain whether the regulation furthers an important or substantial governmental interest. This part of the "inquiry concerns the fit between the asserted interests and the means chosen to advance them." ${ }^{332}$ Under part two of the $O^{\prime} B r i e n$ test, the government "may employ the means of its choosing" as long as the "regulation promotes a substantial governmental interest that would be achieved less effectively absent the regulation." ${ }^{333}$ In this context, therefore, the Court has held that a government "must be allowed a reasonable opportunity to experiment with solutions to admittedly serious problems.",334 Even if a court doubts that the regulation will "greatly" reduce the problem to be solved," $O$ 'Brien requires only that the regulation further the interest" identified by the government. ${ }^{335}$ It is thus left to the "responsible decisionmaker" to determine the "most appropriate method for promoting significant government interests." 336 The Court's explanation of this second inquiry in $O$ 'Brien is what affords regulations of conduct more leeway than regulations of speech because strong evidence is required to restrict speech, but

328. United States v. O'Brien, 391 U.S. 367, 377 (1968).

329. Lawrence O. Gostin, Public Health Law: Power, Duty, Restraint 80-81 (2001).

330. Sligh v. Kirkwood, 237 U.S. 52, 59 (1915); see also Hillsborough Cnty. v. Automated Med. Labs, Inc., 471 U.S. 707, 719 (1985) ("[T] he regulation of health and safety matters is primarily, and historically, a matter of local concern.").

331. City of Erie v. Pap's A.M., 529 U.S. 277, 296 (2000); see also Barnes v. Glen Theatre, Inc., 501 U.S. 560, 569 (1991) (The "traditional police power of the States is defined as the authority to provide for the public health, safety, and morals, and we have upheld such a basis for legislation.").

332. Turner Broadcasting System v. FCC, 520 U.S. 180, 213 (1997).

333. Id. at 213-14.

334. City of Erie v. Pap's A.M., 529 U.S. 277, 301 (2000) (citing Renton v. Playtime Theatres, Inc., 475 U.S. at 52).

335. Id.

336. Turner Broadcasting System, 520 U.S. at 218 (quoting United States v. Albertini, 472 U.S. $675,689(1985))$. 
courts are permitted to defer to legislative judgment to regulate conduct. ${ }^{337}$

The third requirement for a regulation to pass the $O^{\prime} B r i e n$ test is that the government interest must be unrelated to the suppression of free expression. ${ }^{338}$ Thus, the regulation must be "content-neutral." This means that the regulation must not target expression according to its content, and the government must also justify the regulation without reference to the content of the regulated speech. ${ }^{339}$ For example, an ordinance that prohibits the posting of signs on public property regardless of their message is contentneutral. ${ }^{340}$ In contrast, a law restricting the transmission of cable television channels dedicated to programming labeled sexually oriented is contentbased. $^{341}$ Regulations are subject to a stricter analysis than $O^{\prime} B r i e n$ provides if they are content-based or directed at and restrict speech instead of conduct. $^{342}$ (In the commercial speech context, such a restriction would be subject to Central Hudson analysis. ${ }^{343}$ )

337. See Brown v. Entm't Merchs. Ass'n, 131 S. Ct. 2729, 2738 (2011) ("Rather, relying upon our decision in Turner Broadcasting System, Inc. v. FCC, 512 U.S. 622 (1994), the State claims that it need not produce such proof because the legislature can make a predictive judgment that such a link exists, based on competing psychological studies. But reliance on Turner Broadcasting is misplaced. That decision applied intermediate scrutiny to a content-neutral regulation. Id. at 661-662, $114 \mathrm{~S}$. Ct. 2445 . California's burden is much higher, and because it bears the risk of uncertainty . . . ambiguous proof will not suffice."); Turner Broadcasting System, 512 U.S. at 665 ("We agree that courts must accord substantial deference to the predictive judgments of Congress. Sound policymaking often requires legislators to forecast future events and to anticipate the likely impact of these events based on deductions and inferences for which complete empirical support may be unavailable.") (internal citation omitted); see also Lorillard Tobacco Co. v. Reilly, 533 U.S. 525, 558 (2001) (finding the state passed the third prong of Central Hudson by relying on substantial amount of evidence); 44 Liquormart, Inc. v. Rhode Island, 517 U.S. 484, 505 (1996) (government failing prong three because it did not present evidence that its price-advertising ban would significantly reduce alcohol consumption).

338. United States v. O'Brien, 391 U.S. 367, 377 (1968).

339. Boos v. Barry, 485 U.S. 312, 320 (1988) (citing Va. Pharmacy Bd. v. Va. Citizens Consumer Council, Inc., 425 U.S. 748, 771 (1976)).

340. Members of the City Council of Los Angeles v. Taxpayers for Vincent, 466 U.S. 789, 805-807 (1984).

341. United States v. Playboy, 529 U.S. 803, 813 (2000) (Because the Act designated cable channels based on the content of the programming, it could not be analyzed under $O$ 'Brien, and instead was subject to strict scrutiny.); see also Frisby v. Schultz, 487 U.S. 474, 481 (1988) ("For the State to enforce a content-based exclusion it must show that its regulation is necessary to serve a compelling state interest and that it is narrowly drawn to achieve that end.") (quoting Perry Educ. Ass'n. v. Perry Local Educ. Ass'n, 460 U.S. 37, 45 (1983)).

342. Texas v. Johnson, 491 U.S. 397 (1989); see also Spence v. Washington, 418 U.S. 405 (1974). In the realm of traditional political speech, such measures would be subject to strict First Amendment scrutiny. See, e.g., Texas v. Johnson, 491 U.S. 397, 412-14 (1989) (holding that the government may not prohibit expression of an idea merely because it finds the idea offensive; therefore, Johnson's conviction for flag burning in a show of political expression and protest must be subject to "the most exacting scrutiny" rather than $O$ 'Brien's more lenient standard).

343. See, e.g., Lorillard Tobacco Co., 533 U.S. at 567 ("By contrast to Justice Stevens, we do not believe this regulation can be construed as a mere regulation of conduct under United States $v$. O'Brien. To qualify as a regulation of communicative action governed by 
The final inquiry under $O^{\prime} B r i e n$ is to determine whether any incidental restrictions on alleged First Amendment freedoms are no greater than necessary to further the government's interest. The Court confirmed that when it evaluates "a content-neutral regulation which incidentally burdens speech, [it] will not invalidate the preferred remedial scheme because some alternative solution is marginally less intrusive on a speaker's First Amendment interests." 344 Therefore, as long "as the means chosen are not substantially broader than necessary to achieve the government's interest, . . . the regulation will not be invalid simply because a court concludes that the government's interest could be adequately served by some less-speechrestrictive alternative." ${ }^{345}$ The Court thus looks to whether the regulation is narrowly tailored to eliminate the harms the government seeks to rectify, without significantly restricting a substantial quantity of speech that does not create the same harms. ${ }^{346}$ Part four of $O^{\prime}$ Brien requires the court to ensure that the government properly confined the breadth and burden of the regulation. $^{347}$

\section{Other Standards to Regulate Conduct}

It is important to note that in Lorillard, the Supreme Court analyzed Massachusetts' regulation of self-service displays not only in light of $O$ 'Brien, but also under the standard derived from cases involving the regulation of the "time, place and manner" of protected speech. Prior to Lorillard, the Court had noted the essential equivalence of the O'Brien "conduct" test and the time, place, and manner analysis, observing that the two regimes "embody much [of] the same standards." 348 The time, place and manner test is often applied to zoning $\operatorname{cases}^{349}$ or cases involving re-

the scrutiny outlined in $O^{\prime} B r i e n$, the State's regulation must be unrelated to expression. Here, Massachusetts' height restriction is an attempt to regulate directly the communicative impact of indoor advertising.") (internal citations omitted).

344. Turner Broad. Sys., Inc. v. FCC, 520 U.S. 180, 217-18 (1997).

345. Id. at 218 (quoting Ward v. Rock Against Racism, 491 U.S. 781, 800 (1989)).

346. Id. at 216.

347. Clark v. Cmty. for Creative Non-Violence, 468 U.S. 288, 299 (1984); see also Ward v. Rock Against Racism, 491 U.S. 781 (1989).

348. Barnes v. Glen Theatre, Inc., 501 U.S. 560, 566 (1991); see also Clark v. Cmty. for Creative Non-Violence, 468 U.S. 288, 299 n.8 (1984).

349. The time, place and manner test has also been applied to zoning ordinances, which are a form of content-neutral regulation. In his concurring opinion in Lorillard, Justice Thomas distinguished valid zoning restrictions from those struck down in the case. Massachusetts had argued that the 1,000 feet restrictions were "'zoning-type restrictions' that should receive 'the intermediate level of scrutiny traditionally associated with various forms of 'time, place, and manner' regulations." 'Lorillard Tobacco Co., 533 U.S. at 573 (Thomas, J., concurring). However, the Court analyzed them under Central Hudson and found that they failed prong four of that test. Thomas explained that the regulations could not be considered valid zoning laws, and should not be analyzed under the time, place, and manner test because they were not content-neutral. Id. (Thomas, J., concurring) (citing Ward v. Rock Against Racism, 491 U.S. 781, 791-96 (1989)). The 1000 feet restriction was based on the billboards' tobacco-based content. The cornerstone of valid time, place, and manner regula- 
strictions on speech on government property. ${ }^{350}$ Under this test, the government may impose reasonable restrictions "on the time, place, or manner of protected speech, provided the restrictions 'are justified without reference to the content of the regulated speech, that they are narrowly tailored to serve a significant governmental interest, and that they leave open ample alternative channels for communication of the information." 351 The Court's analysis of the tobacco display regulations drew from principle and precedent in both lines of cases.

Apart from the ban on self-service displays of tobacco products upheld in Lorillard Tobacco Co. v. Reilly, few cases directly address the regulation of product location within a store in the context of the First Amendment. In one of the few, Village of Hoffman Estates v. Flipside, Hoffman Estates, Inc., a store called Flipside challenged an ordinance regulating the sale of the drug paraphernalia within the proximity of literature about illegal drug use because it wanted to continue placing certain items at the point of purchase for fear of shoplifting. ${ }^{352}$ The Court held that "insofar as any commercial speech interest is implicated here, it is only the attenuated interest in displaying and marketing merchandise in the manner that the retailer desires. We doubt that the village's restriction on the manner of marketing appreciably limits Flipside's communication of information."353 The Court found that the ordinance did not restrict commercial speech, but rather regulated "business behavior," and thus it did not subject the ordinance to the Central Hudson test. ${ }^{354}$

Although the Court did not cite $O^{\prime}$ Brien in Flipside, the analysis in the case is similar to that in Lorillard. In both cases, the Court acknowledged the existence of a potential commercial speech interest. However, in Lorillard, the Court upheld the ban on self-service displays as a regulation of conduct under O'Brien, whereas in Flipside, the Court simply stated that the law "does not reach constitutionally protected conduct." 355 This likely reflects the evolution of the commercial speech doctrine over time. Since the inception of the commercial speech doctrine, the Court has increasingly interpreted the First Amendment to provide more stringent protection to commercial expression over the years. ${ }^{356}$

tions is their content-neutrality.

350. Clark v. Cmty. for Creative Non-Violence, 468 U.S. 288, 293 (1984); see also Heffron v. Int'l Soc'y for Krishna Consciousness, Inc., 452 U.S. 640, 647 (1981); Galena v. Leone, 638 F.3d 186, 199 (3d Cir. 2011).

351. Ward v. Rock Against Racism, 491 U.S. 781, 791 (1989) (quoting Clark v. Cmty. for Creative Non-Violence, 468 U.S. 288, 293 (1984)).

352. Vill. of Hoffman Estates v. Flipside, Hoffman Estates, Inc., 455 U.S. 489 (1982).

353. Id. at 496 (emphasis omitted).

354. Id. at 496-499.

355. Id. at 497.

356. See, e.g., Sorrell v. IMS Health Inc., 131 S. Ct. 2653, 2685 (2011) (Breyer, J., dissenting) (referring to lack of precedent for subjecting the type of regulation at issue to the Central Hudson test and expressing concern that the majority opinion will open "a Pandora's Box of First Amendment challenges to many ordinary regulatory practices that may only 


\section{Constitutional Analysis of the In-Store Regulations}

There are two practical options that can be implemented at a state or local level that the government could consider in addressing in-store promotions: regulate the location of products not meeting nutritional guidelines or products bearing characters on the packaging that do not meet nutritional guidelines. ${ }^{357}$ Within the retail environment, the key locations to consider are shelf level and location, special displays such as end-cap displays, and check-out aisles.

\section{Regulating Product Location Based on Nutritional Criteria}

The government could determine that it wants to regulate the location of unhealthy food products by designating products solely according to their nutritional profiles. Because there is no expressive component to nutritional profiles, it would be difficult for industry to argue that this is a regulation of commercial expression. The government could enact strong nutritional guidelines for foods to be placed in specific areas such as at the check-out or in the bulk displays located at the end of aisles. The government could likewise regulate the location of specific products according to nutritional profile, such as sugar-sweetened beverages, so that they must be placed in destination locations in the back of the store.

If the government were to regulate the location of food and beverage products within a retail establishment based solely on nutrition criteria, the government would have a strong argument that this is a pure regulation of conduct, not implicating the First Amendment. ${ }^{358}$ Requiring retailers to alter the location of a product within the store based solely on a nonexpressive element such as nutrition criteria should be considered a regulation of pure conduct.

The Ninth Circuit upheld San Francisco's ban on pharmacies selling tobacco products, explaining that selling cigarettes is not protected expressive activity because "[i]t doesn't even have 'an expressive component."

incidentally affect a commercial message").

357. A regulation based only on the use of character would be over-inclusive to address nutrition. Characters may be found on healthy products or products only for adults or nonfood products. Cf. Bad Frog Brewery, Inc. v. N.Y. State Liquor Auth.,134 F.3d 87, 92 (2d Cir. 1998) (reminding the parties that other characters have been used to market beer, including the Budweiser Frogs, Spuds Mackenzie and the Bud-Ice Penguins, and rejecting the advertising restrictions).

358. Arcara v. Cloud Books, Inc., 478 U.S. 697, 706-707 (1986) ("[W]e have subjected such restrictions to scrutiny only where it was conduct with a significant expressive element that drew the legal remedy in the first place, as in $O^{\prime} B r i e n$, or where a statute based on a nonexpressive activity has the inevitable effect of singling out those engaged in expressive activity, as in Minneapolis Star. This case involves neither situation, and we conclude the First Amendment is not implicated by the enforcement of a public health regulation of general application against the physical premises in which respondents happen to sell books.").

359. Philip Morris USA, Inc. v. City and Cnty. of S.F., 345 Fed. Appx. 276, 277 (9th 
The Ninth Circuit held that the sale of an item is pure conduct and not protected by the First Amendment. ${ }^{360}$

In the context of private litigation, where the court is not analyzing a government restriction on speech under the First Amendment, but rather analyzing private parties' actions implicating another party's communication interests, courts have found that shelf placement and location within retail environments are not speech. In the antitrust context, courts have found that moving a product to a location a manufacturer deems less ideal does not implicate the company's ability to communicate with consumers. ${ }^{361}$ In the context of a trademark infringement and false advertising lawsuit, a district court found that a retailer's display of a product under the wrong name and in the incorrect shelf location was not actionable because the display of products in a certain location does not constitute "commercial advertising or promotion." 362 The Eleventh Circuit affirmed the district court's opinion, in which the district court explained:

$[\mathrm{P}]$ roduct placement is not commercial speech . . . . It is difficult to see how merely displaying products on a store shelf qualifies as speech . . . . If product placement such as that alleged here was sufficient to constitute commercial advertising or promotion, grocery store aisles, with competing products displayed one after another and often inadvertently placed over an

Cir. 2009) (quoting Talk of the Town v. Dep't of Fin. \& Bus. Servs., 343 F.3d 1063, 1069 (9th Cir. 2003) (citing Arcara, 478 U.S. at 701-02, 706 (1986)); $c f$. Lorillard Tobacco Co., 533 U.S. at 550.

360. Cf. Ginsberg v. N.Y., 390 U.S. 629, 638 (1968) (Although decided under the First Amendment, and not as a regulation of conduct, the Supreme Court noted that government has power "to control the conduct of children" that "reaches beyond the scope of its authority over adults.").

361. Antitrust lawsuits provide an interesting lens through which to view the food industry's concerns with respect to shelf location. For example, in R.J. Reynolds Tobacco Co. v. Philip Morris USA, Inc., 199 F. Supp. 2d 362 (M.D. N.C. 2002), aff'd, 67 Fed. Appx. 810 (4th Cir. 2003), competing tobacco companies sued Philip Morris ("PM") for anticompetitive behavior under the Sherman Action. The relevant portions of the complaint alleged that PM was paying retailers for advantageous signage space and displays of their products, which plaintiffs alleged restricted the flow of their information to consumers. Id. at 380-81. The court found that, although retailers that sign onto PM's program do give more advantageous display and sign space to PM products, plaintiffs were not excluded from posting signs or displaying their products in alternative locations in the store, (or even entering in their own agreements with retailers for more advantageous visibility). The court found as a matter of law that PM's practice "does not unreasonably deny consumers needed information." Id. at 396. Importantly, the court concluded that plaintiffs ability to communicate in other places within the store, other than the most prime visibility locations, did not unreasonably deny consumers commercial information. See also El Aguila Food Prods., Inc. v. Gruma Corp., 301 F. Supp. 2d 612 (S.D. Tex. 2003), aff'd, 131 Fed. Appx. 450 (5th Cir. 2005).

362. Optimum Techs., Inc. v. Home Depot USA, Inc., No. 1:04-CV-3260-TWT, 2005 U.S. Dist. LEXIS 34776, at *19-20 (N.D. Ga. December 5, 2005), aff'd, 217 Fed. Appx. 899 (11th Cir. 2007). 


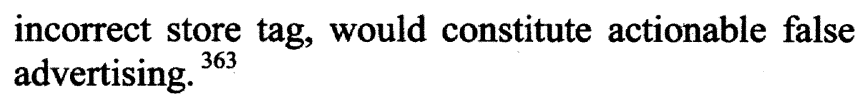

These cases confirm that courts accept the proposition that the placement of products in locations not considered ideal to the manufacturer does not cut off their ability to communicate with customers. This measure is applicable and legally defensible for unhealthy food products to protect children without implicating commercial speech. ${ }^{364}$

By locating items of poor nutritional value out of checkout aisles or end-cap displays, ${ }^{365}$ and placing healthier items (or non-food items) in their place, such an ordinance leaves open alternative channels for vendors to sell and convey the same information about their products. Likewise, such relocation does not impede consumers' access to these exact same products because they would be located elsewhere in the store. ${ }^{366}$

Once outside the purview of the First Amendment, the government must only show that the regulation is rationally related to a legitimate government interest. ${ }^{367}$ Here, this would be a valid regulation of "commercial transactions," 368 or "business behavior," "369 that rests on a rational basis and should be upheld under this criterion.

\section{Regulating Product Location Based on Nutritional Criteria and Character Use}

The second method to positively influence the food choices by chil-

363. Id. (internal citations omitted).

364. See also Bad Frog Brewery v. N.Y. State Liquor Auth., 134 F.3d 87, 98-99 (2d Cir. 1998). Under a discussion of why a commercial speech restriction failed prong four of the Central Hudson test, the Second Circuit suggested in store regulation of the location of the product would have been a viable alterative to regulating speech. The Second Circuit did not analyze its suggestion, but it is worth noting the measure it found was available to the state: "to whatever extent [the state] is concerned that children will be harmfully exposed to the Bad Frog labels when wandering without parental supervision around grocery and convenience stores where beer is sold, that concern could be less intrusively dealt with by placing restrictions on the permissible locations where the appellant's products may be displayed within such stores." Id. at 101 .

365. Gale Group. Confection detection: creative merchandising works - Food - Candy stores-within-a-store concept offer colorful, interactive displays - Brief Article DSN Retailing Today, June 24, 2002 ("The key to location is realizing candy is an impulse purchase. It reacts more to a display than it does to price.")

366. Lorillard Tobacco Co., 533 U.S. at 569-70.

367. Ysursa v. Pocatello Educ. Ass'n, 172 L. Ed. 2d 770, 778 (2009) ("Given that the State has not infringed the unions' First Amendment rights, the State needs only demonstrate a rational basis to justify the [law].").

368. Sorrell, 131 S. Ct. 2653 at 2675 (Breyer dissenting) (“"[R]egulatory legislation affecting ordinary commercial transactions is not to be pronounced unconstitutional' if it rests 'upon some rational basis within the knowledge and experience of the legislators."') (quoting United States v. Carolene Products Co., 304 U.S. 144, 152 (1938).

369. Flipside, 455 U.S. at 499. 
dren would be to regulate the location of food products of poor nutritional quality also bearing characters to address the poor nutrition-related beliefs and behaviors of children. By addressing the use of characters on unhealthy food products, the regulation would be directly moving the problem products to make the default choice the healthy choice and allow adults shopping with children to avoid specific areas of the retail environment. This would not be suppressing speech but simply moving it to another location. It would also not address more character use than essential. Thus, characters on healthy products (such as carrots) would not be regulated. ${ }^{370}$ The regulation could likewise exclude characters on products only legally purchasable by adults, such as beer, in order to address the harm the government seeks to rectify, without restricting speech that does not create the same harm. ${ }^{371}$

Regulating the location of products according to the nutrition profile and use of characters may spur a legal challenge by retailers and/or manufacturers, who would argue that the characters are a form of commercial speech and that the regulation violates their First Amendment rights of commercial expression. The first question is whether the use of cartoon characters is a form of commercial speech. Section 5.B.1., above, analyzed the use of characters on unhealthy food products under the theory that they are deceptive to children and thus not protected by the First Amendment. The government would want to assert the same argument here as well. If a court disagrees, it would find that the characters are a form of commercial expression.

The second question is whether regulating the location of the products bearing such characters interferes with the industry's First Amendment rights of expression. The government has a valid argument that simply moving products within a store is pure regulation of conduct and could cite the precedent discussed above. However, the industry would argue that designating a product according to the use of characters is content-based. If a court did not agree that this was a pure regulation of conduct, the closest precedent to the proposed regulation here would be the ban on self-service displays upheld in Lorillard as a regulation of expressive conduct. ${ }^{372}$ Like

370. A regulation aimed solely at moving products with illustrations would seem to be ill-tailored because it would implicate healthy products (such the "Sun-Maid Girl" on raisins, or carrots with characters), products for adults, thus not furthering the government's public health interests, so could be considered overbroad.

371. Turner Broadcasting System v. FCC, 520 U.S. 180, 216 (1997); see, e.g., Bad Frog Brewery, 134 F.3d at 92 (The court reminded the parties that other characters have been used to market beer, including the Budweiser Frogs, Spuds Mackenzie and the Bud-Ice Penguins and rejected the advertising restrictions).

372. Lorillard Tobacco Co. v. Reilly, 533 U.S. 525, 567 (2001) (citing 940 Code of Mass. Regs. $\S \S 21.04(2)(c)-(d), 22.06(2)(c)-(d)(2000)$ ) (The regulations' stated purpose was to minimize customer access without proper age verification to prevent minors from obtaining tobacco products.). 
in Lorillard, the state would be seeking to regulate conduct "that may have a communicative component," but altering the location of the products within the retail establishment "for reasons unrelated to the communication of ideas." 373 Under this precedent, a court should analyze the retail regulation under $O^{\prime} B$ Bien. ${ }^{374}$

\section{a. Analysis under $O^{\prime}$ Brien}

Under $O^{\prime} B r i e n$ analysis, a court will first ask if such regulations are within the constitutional power of the government. ${ }^{375}$ State and local governments can regulate retail establishment to further public health under their traditional police power. ${ }^{376}$ For example, in the tobacco context, governments often require tobacco retailers to be licensed and to agree to certain conditions, such as not selling cigarettes to children, in order to operate. ${ }^{377}$ This proposed regulation of the retail environment would be similar public health regulations of retailers enacted as part of the state and local governments' police power.

Second, courts ask if the regulations will further an important or substantial governmental interest. ${ }^{378}$ In the case of retail food regulations, the government would have several rationales for locating unhealthy items with characters in destination locations. The state has an interest in protecting children from overreaching by commercial entities and correcting children's poor nutrition-related beliefs and behaviors that result from such overreaching. ${ }^{379}$ The regulation seeks to support public health by making the locations most frequented in the store supportive of making healthy choices, thus encouraging healthy default choices. In addition, by requiring unhealthy products directed at children to be placed in destination locations, this would enable adults to avoid the products when shopping with children, thereby bolstering parents and guardians in their roles as nutritional gatekeepers. ${ }^{380}$

The government has a valid argument that these public health and consumer protection rationales will be furthered by the regulations within retail establishments. In this context, the Court has held that under $O^{\prime} B r i e n$,

373. Id. at 570 (internal citations omitted).

374. Id. at 569.

375. United States v. O'Brien, 391 U.S. 367, 377 (1968).

376. City of Erie v. Pap's A.M., 529 U.S. 277, 296 (2000); Gostin, supra note 337, at 282-83.

377. See, e.g., New York Laws: New York City Administrative Code: Tobacco Product Regulation Act. §§ 17-616 - 17-626.

378. O'Brien, 391 U.S. at 377.

379. Bd. of Trs. of the State Univ. of N.Y. v. Fox, 492 U.S. 469 (1989).

380. Bellotti v. Baird, 443 U.S. 622, 634 (1979); FCC v. Pacifica Foundation, 438 U.S. 726,749 (1978) (quoting Ginsberg v. New York, 390 U.S. 629) (the government's interest in "supporting 'parents' claim to authority in their own household" justifies restricting otherwise protected expression). 
a government "must be allowed a reasonable opportunity to experiment with solutions to admittedly serious problems." "381 Even if a court doubts that the regulation will "greatly" reduce the problem to be solved, " $O$ 'Brien requires only that the regulation further the interest" identified by the government. $^{382}$ Based on the research delineated above, the government can establish that the regulations would further these public health and consumer protection interests.

Third, the court will ask if the governmental interest is unrelated to the suppression of free expression; ${ }^{383}$ this means that the regulation must not target expression according to its content and the government must also justify the regulation without reference to the content of the regulated speech. ${ }^{384}$ Industry might argue that the regulation is not content-neutral because it incorporates the use of characters, which it considers to be protected speech. The government would argue that regulation does not target expression because it is not disagreeing with any message that the manufacturer is attempting to convey by using characters on its packaging or any message the retailer may have by locating the products in their original locations. Rather, the government would simply be seeking to move these messages to another location within the same retail establishment for the reasons delineated in the second inquiry above, thereby moving any expressive component to a different location-not to suppress the expression itself. The industry would likely challenge the content neutrality of the regulation by arguing that designating a product by reference to the use of a cartoon character would be content-based. It is worth analyzing to what extent this is a valid argument under the $O$ 'Brien test.

\section{(I) Content-neutrality}

In Lorillard the Court did not expand on the content-neutrality of the regulation upheld under O'Brien. Apart from Lorillard, the Court had not applied $O$ 'Brien to expressive commercial conduct but the closest case on point is Flipside v. Hoffman Estates where the Court upheld the city's ordinance which moved the location of commercial products within the retail environment. The ordinance in that case "licenses and regulates the sale of items displayed 'with' or 'within proximity of' 'literature encouraging illegal use of cannabis or illegal drugs,' .... [and] drug-related designs or names on cigarette papers may subject those items to regulation." Howev-

381. City of Erie v. Pap's A.M., 529 U.S. 277, 301 (2000) (citing Renton v. Playtime Theatres, Inc., 475 U.S. 41, 52 (1986) (quoting Young v. American Mini Theatres, 427 U.S. 50,71 (1976) (plurality opinion))).

382. Id.

383. O'Brien, 391 U.S. at 377.

384. Boos v. Barry, 485 U.S. 312, 320 (1988) (quoting Virginia Pharmacy Bd. v. Virginia Citizens Consumer Council, Inc., 425 U. S. 748, 771 (1976)). 
er, the Court found that, "the village does not restrict speech as such, but simply regulates the commercial marketing of items that the labels reveal may be used for an illicit purpose." ${ }^{385}$ Thus the Court recognized that the method to determine which commercial speech was subject to the ordinance was to look at the content of the label. ${ }^{386}$ The purpose of the regulation was not to limit the speech but move it to a different location. On this latter point, the Court concluded that, "insofar as any commercial speech interest is implicated here, it is only the attenuated interest in displaying and marketing merchandise in the manner that the retailer desires. We doubt that the village's restriction on the manner of marketing appreciably limits Flipside's communication of information." 387

Based on this case, the government has a good argument that moving the location of items defined through nutrition profile and the use of characters should withstand First Amendment scrutiny. The Court's commercial speech jurisprudence has evolved since Flipside, so a comparison to two cases concerning core speech (which is strictly protected) can also flesh out the concept of content-neutrality. In Boos v. Barry, the Court found the restriction at issue to be content-based. In that case Washington, D.C. attempted to prohibit individuals from displaying signs 500 feet from foreign embassies if the sign brought that foreign government into "public disrepute." ${ }^{388}$ The Court found this regulation to be content-based because it prohibited political speech based on the content of the speech in a public forum. ${ }^{389}$ The Court noted that the city attempted to justify the regulation based on the need to protect the "dignity of foreign diplomatic personnel. ${ }^{390}$ Disregarding the forum and political aspect of the speech, the case

385. Vill. of Hoffman Estates v. Flipside, 455 U.S. 489, 496 (1982).

386. See also Hill v. Colorado, 530 U.S. 703, 721-22 (2000) ("It is common in the law to examine the content of a communication to determine the speaker's purpose. Whether a particular statement constitutes a threat, blackmail, an agreement to fix prices, a copyright violation, a public offering of securities, or an offer to sell goods often depends on the precise content of the statement. We have never held, or suggested, that it is improper to look at the content of an oral or written statement in order to determine whether a rule of law applies to a course of conduct. With respect to the conduct that is the focus of the Colorado statute, it is unlikely that there would often be any need to know exactly what words were spoken in order to determine whether 'sidewalk counselors' are engaging in 'oral protest, education, or counseling' rather than pure social or random conversation. Theoretically, of course, cases may arise in which it is necessary to review the content of the statements made by a person approaching within eight feet of an unwilling listener to determine whether the approach is covered by the statute. But that review need be no more extensive than a determination of whether a general prohibition of 'picketing' or 'demonstrating' applies to innocuous speech. The regulation of such expressive activities, by definition, does not cover social, random, or other everyday communications. . . . Nevertheless, we have never suggested that the kind of cursory examination that might be required to exclude casual conversation from the coverage of a regulation of picketing would be problematic.").

387. Vill. of Hoffman Estates, 455 U.S. at 496.

388. Boos v. Barry, 485 U.S. 312, 315 (1988).

389. Id. at 319 .

390. Id. at 321. 
nonetheless addressed a ban on content-based political expression. Even in the context of political expression the outcome could have been different if the ordinance just required the protesters with such signs to move to another location outside the embassies. The case of Hill v. Colorado stands for this proposition. $^{391}$

In Hill v. Colorado, the Court sought to determine the constitutionality of a statute prohibiting people from approaching one another within 100 feet of the entrance to any health care facility to engage in protest or education. The principal inquiry in the Court's analysis of content-neutrality was to determine "whether the government has adopted a regulation of speech because of disagreement with the message it conveys.",392 The Court found that the statute was content-neutral because it did not regulate speech, but rather regulated "the places where some speech may occur;" it was not adopted because the government disagreed "with the message it conveys" because it equally applied to all demonstrators regardless of the viewpoint. ${ }^{393}$ The Court specifically stated: "We have never held, or suggested, that it is improper to look at the content of an oral or written statement in order to determine whether a rule of law applies to a course of conduct.",394

In the case of regulation of products within retail environments, the government would likewise not be regulating speech but rather regulating the place where some speech may occur. Second, the government does not disagree with a message that a cartoon character may indicate but simply requires a "cursory examination" of the package to identify which packages fall under the ordinance. ${ }^{395}$ The regulation would cover all products with a

391. The majority in Colorado v. Hill noted that the persons going into the health care center would be unwilling listeners and compared them to a captive audience. Captive audience jurisprudence is based on a privacy interest, and in this case it was the access to health care. Hill, 530 U.S. at 718 . Although a similar privacy interest would not likely attach to a supermarket experience, an analogy could be drawn because going into a food store is a necessity to obtain food and further, in order to purchase food, customers must exit through a check-out aisle which is lined with items known to induce impulse purchases. Erznoznik v. City of Jacksonville, 422 U.S. 205, 209, 210-11 (1975); see also Lehman v. City of Shaker Heights, 418 U.S. 298, 302 (1974). Even if a court does not perceive customers to be a captive audience, this is how retailers view them. Restrictions on traditional speech have been upheld when the listener has been considered captive and unable to avoid offensive speech. In Lehman, the Court found that riders on the city's public transit system were a captive audience, and the city could reject political advertisements on its vehicles. The Court found that the "streetcar audience is a captive audience. It is there as a matter of necessity, not of choice." Id. at 302 . Likewise, a food store is a place one goes out of necessity and the checkout aisle is a place one must enter and cannot avoid in order to purchase food necessities. In the school context the Court has recognized that children are a captive audience and has afforded increased protection from exposure to sexually explicit, indecent, or lewd speech. See Bethel Sch. Dist. v. Fraser, 478 U.S. 675, 684 (1986).

392. Hill, 530 U.S. at 718 (quoting Ward v. Rock Against Racism, 491 U.S. 781, 791 (1989)).

393. Id. at 719-20.

394. Id. at 722 .

395. Id. 
character that do not meet the nutritional guidelines, not differentiating among potential "messages" that the character is cute, funny or "creepy.",396 Because the character restriction is based on nutritional guidelines and not on the type of character, the regulation would not be choosing among different types of characters or messages that different characters may be attempting to send from an industry perspective.

One purpose behind the ban on self-service displays in Lorillard Tobacco Co. v. Reilly, was to move tobacco products to areas where children could not access them. ${ }^{397}$ Similarly, the supermarket restrictions would be moving harmful products to different locations so adults accompanied by children can avoid if they so wish. The Second Circuit suggested this exact measure to protect children in the retail environment from seeing a "vulgar" character on beer labels:

[T]o whatever extent [the state] is concerned that children will be harmfully exposed to the Bad Frog labels when wandering without parental supervision around grocery and convenience stores where beer is sold, that concern could be less intrusively dealt with by placing restrictions on the permissible locations where the appellant's products may be displayed within such stores. ${ }^{398}$

The Court's reasoning in Tennessee Secondary School v. Brentwood is also relevant. ${ }^{399}$ The Court recognized the need to protect "impressionable middle school" children from overreaching by a letter from a sports coach, as a "hard-sell tactic." ${ }^{400}$ In the case of a letter, the parent retrieves the mail and could control whether to give the middle school child the letter. In the supermarket, parents cannot similarly shield their children from all food packaging. In Brentwood, the letter came from a coach seeking to solicit participation in football- the Court found that this "could lead to exploitation, distort competition between high school teams, and foster an environment in which athletics are prized more highly than academics. ${ }^{, 401}$ In the supermarket, the characters are certainly a hard-sell tactic because they induce purchase requests by children who do not even know what is in the packaging and also influence children to prefer the food with the character.

396. Derek Thompson, Burger King's Horrible, Creepy Ad Campaign isn't Working, The Atlantic, June 22, 2009, http://www.theatlantic.com/business/archive/2009/06/burgerkings-horrible-creepy-ad-campaign-isnt-working/19870/.

397. Lorillard Tobacco Co., 533 U.S. at 567.

398. Bad Frog Brewery v. N.Y. State Liquor Auth., 134 F.3d 87, 101 (2nd Cir. 1998).

399. Tenn. Secondary Sch. Athletic Ass'n v. Brentwood Acad., 551 U.S. 291 (2007).

400. Id. at 296.

401. Tenn. Secondary Sch. Athletic Ass'n v. Brentwood Acad., 551 U.S. 291, 300 (2007). 
A similar argument can be made that this fosters an environment where packaging is "prized more" than the food contained therein, and especially healthy nutritious food. The government has a valid argument that the regulation is content-neutral and the court should proceed to the fourth inquiry under $\mathrm{O}$ 'Brien

\section{b. O'Brien inquiry continued}

Under the final inquiry under O'Brien, the government must show that any incidental restriction on alleged First Amendment freedoms is no greater than is essential to further that interest. ${ }^{402}$ Even if the manufacturers and retails had some kind of expressive interest in the original location of the products, by placing the products in the new location within the same retail establishment, any incidental restriction on alleged First Amendment freedoms would be no greater than is essential to further that interest. ${ }^{403}$ This paper explored several other options in order to address the problem of character marketing on unhealthy food and beverages. These regulations of conduct are the least restrictive available to state governments, while also addressing the problem sought to be rectified.

In the food context, the government has evidence that regulating the location of products does alter consumer behavior. ${ }^{404}$ The government has a good argument that the retail establishment regulations are narrowly tailored to eliminate the harms the government seeks to rectify, without significantly restricting any quantity of speech that does not create the same harms. ${ }^{405}$ Thus even assuming retailers and manufacturers have a cognizable speech interest in the original means or location of displaying their products, the ordinances should pass this part of the test because the expressive components are simply being moved to a different location and are not being suppressed. ${ }^{406}$ Given that the retail food environment fosters purchase of foods high in calories and low in nutrients and that some of the worst foods are placed where impulse purchases are most likely, a strong argument can be made that government has a compelling interest in changing this environment, particularly as it affects children. ${ }^{407}$

402. United States v. O’Brien, 391 U.S. 367, 377 (1968).

403. Id.

404. See, e.g., Gale Grp. Confection Detection: Creative Merchandising Works - Food - Candy Stores-Within-a-Store Concept Coffer Colorful, Interactive Displays - Brief Article DSN Retailing Today (June 24, 2002), http://findarticles.com/p/articles/mi_m0FNP /is_12_41/ai_87776891/ ("The key to location is realizing candy is an impulse purchase. It reacts more to a display than it does to price.").

405. Turner Broad. Sys. v. FCC, 520 U.S. 180, 216 (1997).

406. Lorillard Tobacco Co. v. Reilly, 533 U.S. 525,569 (2001).

407. Brown v. Entm't Merchs. Ass'n, 131 S. Ct. 2729, 2762 (2011) (Breyer J. dissenting) (The "'regulatio[n] of communication addressed to [children] need not conform to the requirements of the [F]irst [A]mendment in the same way as those applicable to adults."') (quoting Ginsberg v. New York, 390 U.S. 629, 638 n.6, (1968) (quoting Thomas Emerson, 


\section{CONCLUSION}

The food retail environment does not support healthy choices and induces children to request and think they prefer unhealthy food because of the use of characters and other promotions on packaging and throughout the store. The government may determine that it has an interest in addressing this environment based on its interests in advancing public health, protecting children from manipulation and commercial exploitation, and supporting parents' role in child-rearing. Based on the best science evidence and within the constraints of the First Amendment, two viable methods to address this environment emerge.

The federal government is in the best position to enact a restriction on the use of characters on packaging for food and beverages that do not meet strong nutritional guidelines. The government can argue that the use of characters on unhealthy food is deceptive and misleading as directed at children and thus not protected under the First Amendment. If a court does not accept this argument, the government would have a strong argument that a well-defined restriction would survive scrutiny under the full Central Hudson test.

Concurrently, or in the absence of federal regulation, state and local governments could regulate the location of such products within retail establishments that do not meet certain nutrition profiles or regulate the location of the same unhealthy products that also bear characters on the packaging. The former should be considered and upheld as a pure regulation of conduct and the latter should be upheld under the test developed in O'Brien.

Government regulation may be warranted in light of the emerging evidence that food retail and package promotions directed at children are primarily for unhealthy food, and this environment is not being addressed by the industry despite self-regulation in other areas. To date government action has largely focused on deceptive or misleading claims on food and beverage packaging directed at adult consumers. Industry has treated children as active consumers for decades and research reveals that this is negatively impacting children's beliefs and behaviors associated with unhealthy food products. Public health and government entities should address this environment by responding to the true role children play in the marketplace. In this way, the government can directly address deceptive and misleading practices targeting child-consumers and enact protective measures based on the most recent science. 
